\title{
A Study of Art and Craft Teaching Programs According to Their Function of Generating "Industrial Design Education" Qualification for Teacher Candidates"
}

\section{Şehnaz YALÇIN WELLS ${ }^{\dagger a}$}

\author{
${ }^{a}$ Marmara University, Atatürk Faculty of Education, İstanbul/Turkey
}

\section{Article Info}

DOI: $10.14527 /$ pegegog.2014.005

Article history:

Received 22 November 2013

Revised 22 January 2014

Accepted 27 January 2014

\section{Keywords:}

Art and craft program,

Fine arts education,

Handcrafting and design,

Industrial design,

Teacher qualifications.

\begin{abstract}
The purpose of this study is to evaluate the function of art and craft teachers programs, based on opinions of teachers graduated from art and craft teachers undergraduate program, for making the teacher candidates gain the "Industrial Design Education" qualification, which is a part of the Fine Arts classes in primary and secondary schools. The research has been conducted with a qualitative research approach. Participants in the research are 43 teachers graduated from Marmara University Atatürk Education Faculty Art and Craft Teaching undergraduate program. Data has been collected by document analysis techniques and surveys developed by the researcher. The transcripts of the teacher candidates graduated at different years from this program are done by examining the documents. The research has been conducted with a qualitative research approach. The research showed that teachers evaluate the industrial design education qualification function of the art and craft teachers undergraduate program according to workshop diversity, workshop course hours, and the content of the program. (i)Teachers are generally negative about the branching that develops in time within the structure of the program. (ii)They think it is a must for teacher candidates to participate in several workshops to gain the required professional qualification for their branch. (iii) And teachers affirm the regulation of craft design workshop as industrial workshop. (iv) they also stress the importance of course hours and program content. On the other hand, teachers make several suggestions about developing the program, the purpose of the program, education method and environment, cooperation between academicians and institutions, so that the art and craft undergraduate program can function more effectively.
\end{abstract}

\section{Introduction}

The purpose, content and methods of art education have gone through enormous changes under the influence of various factors. Paradigms regarding art and art education are among these factors. Today, art education can be commonly described as "the effort to train and educate individuals in the fields of art and culture" (Uysal, 2005: 41). Similarly art education can be described as "an education system that develops the aesthetic sensibilities of students, increases their thinking capabilities, and helps them to become creative and social individuals who are aware of visual realities." (Türe, 2007: 40 Cite in: Şahin, 1999) An art education of high quality requires a perspective that is aware of the value of art education, qualified art educators, sufficient course hours, proper hardware and tools, and an education program that is capable of renewing itself according to changing demands of the times." (Buyurgan \& Buyurgan, 2012). On the other hand, as İz-Bölükoğlu (2002) and Zeren (2006) suggest, the requirements of the

\footnotetext{
* This study is based on the paper presented at the $22^{\text {nd }}$ National Education Sciences Assembly held by Eskişehir Osmangazi University, 5th-7th September, 2013.

† Corresponding author: sehnazwells@marmara.edu.tr
} 
information age and technological means should be reflected in art education environments, and education should be reorganized according to these potentials and requirements.

In Turkey, existing Visual Arts classes of primary and secondary school programs were initiated by MEB (Ministry of National Education) in 2006 (MEB, 2006a). Visual arts education as a field of education have been covering primary and secondary school programs (MEB, 1992; MEB, 2000; MEB, 2006b; MEB, 2010; Peşkersoy \& Yıldırım, 2010) under names like painting, painting and handicraft, and art and craft (Kırışoğlu, 2009). Today what we expect from the education system is not only to supply information but also to develop the talent for creating different ideas, new synthesis and products (Gökay, 2009). In this process children should be assisted in using technology and imagination to become free and creative individuals (Kehnemuyi, 2004). It has been said that designing this class according to multi-intelligence theory would make it more enjoyable (Ayaydın, 2009). However, all this can only be achieved if there is sufficient time devoted to art and craft classes in primary and secondary school programs, and if the environment, material, and necessary tools for these lessons are provided (Özsoy \& Şahan, 2009). Also it can't be denied that education of the teachers in this field is essential for the success of art education.

Today, the main mission of the art and craft teachers undergraduate programs (RIÖLP) in education faculties is to train art educators matching global standards. Undergraduate programs of education faculties have been reconfigured in 1998 by YÖK and art and craft teacher training system has undergone serious changes. Since its enforcement, various opinions have been articulated about the purpose and structure of RiÖLP. These opinions can be grouped as such

1. Students should be educated in all workshops for a minimum of time and then chose their Main Art Workshop. That would allow them to learn various art branches/workshops better before making a choice while also allowing them to know more about various art disciplines as a teacher should.

2. Students attending all workshops is unnecessary and a waste of time; therefore students should chose their Main Art Branch and limited extra workshops.

In the pre-1998 period teacher candidates used to attend all workshops on a rotation basis in their second year, and in their third year students chose their branches. This program design was very important for the multi-dimensional aspect of art and craft teachers education. Yet, after the initiation of RiöLP in 1998, students chose their branches in their second year and apart from their main art workshops they were able to attend two more workshops. Thus teacher candidates began to graduate without getting a proper education about art branches that are necessary for their professional qualification as an art and craft teacher. Programs can be made effective by making necessary changes continuously after observing the applications according to general purposes. As a result, program development is described as a "dynamic process". The first phase of program development is program evaluation (Demirel, 1997; Ertürk, 1993; Oliva, 2001; Varış, 1988).

Despite discussions surrounding changes related to RiÖLP and the functionality of teacher education, we do not have sufficient scientific data because there is no nationwide program evaluation studies in Turkey focusing on education faculty programs. So pilot program development studies carried out by researchers gain additional significance. Yet, research about RiÖLP till today (Ayaydın, 2011; Buyurgan, 2007; Eldemir, 2011; Gökay Yılmaz, 2009; Kavuran, 2003; Kiprik \& Şirin, 2012; Polat, 2013; Sarı, 2000) has been limited to specific issues like student attitudes, student success, student choice and a meta analysis of related research. During literature analysis of the subject we couldn't find any research directly on industrial design education (ETE). This shows us that there is no adequate inquiry about the role of industrial design main art workshop and how RiÖLPs give ETE qualifications to teacher candidates. In this framework, the purpose of this research is to determine the function of RiöLPs in providing the necessary ETE qualification to teacher candidates as a part of Visual Arts/Art and Craft classes, according to teacher's opinions. In this light, answers to following questions have been investigated: 
What does art and craft teaching undergraduate program graduates,

I. think about RiÖLP's role in providing the necessary ETE qualification to teacher candidates?

II. think about reconfigurations in RiÖLP?

III. would like to suggest about RiÖLP practices?

\section{Method}

\section{Research Design}

This research has been designed according to the qualitative research approach. In this study the qualitative approach has been chosen because we investigate the teachers' own opinions, perceptions and expressions about the industrial design education qualification within the undergraduate program they themselves graduated from.

\section{Participants}

The participants in this research are 43 teachers currently working in various private schools and state schools in various towns and cities and who are all graduates of Marmara University Atatürk Faculty of Education Art and Craft Teaching's various main art branches and workshops. Participants have been chosen on a voluntary basis and easy access was a reason for preference.

\section{Instrument}

Data has been collected using survey and document analysis techniques. The survey developed by the researcher includes open ended and close ended 5 demographical information question and 14 open ended questions about the research problem. Document analysis has been carried out on student transcripts who graduated from RiÖLP of the same faculty in various years. During the analysis of transcripts classes, class periods, workshop varieties have been investigated to find out differences in various periods.

\section{Data Analysis}

Data was collected in the 2012-2013 academic year. Surveys were sent to teachers via the Internet. Collected data were analysed with an objective method according to the qualitative content analysis. Objective analysis is realized by coding accessed data and thus finding out concepts lying beneath the data and the relations that exist between concepts (Yıldırım \& Şimşek, 2006). In this light, answers coming from teachers have been made ready and organized for the analysis. Later an open coding procedure has been performed on all data sets. Various connections have been made between codes found out during open coding analysis, thus new categories and themes were found. To ensure the reliability of the data reached during the research the Miles \& Huberman (1994) formula was used to check coherence coding made by two separate experts. As a result $86 \%$ coherence has been determined. Research discoveries have been supported by direct quotes from the expressions of participants.

\section{Results}

In this study RiöLP's function of providing "industrial design education" qualification to teacher candidates is investigated, how much qualification is provided and how are the questions examined. And it is determined that RiÖLP's role in providing ETE qualification is evaluated according to workshop variations, workshop class durations and content of RiÖLP. Teachers have mentioned many benefits of workshop diversity and thus always approached positively to workshop diversity. $72 \%$ of the teachers find class durations insufficient, and they think that this has a negative influence on the quality of education. Evaluating the content of RiÖLP, they find industrial design workshop as one of the most functional workshops. This workshop helps to get awareness about material and information, increase 
will and interest, develop creativity, helps to develop motor/hand skills, thinking and producing three dimensional.

Teachers have a negative opinion about changes in RiÖLP regarding branching. They think early branching causes specialization in one field and is not good for being a teacher. Yet, they think reorganizing craft design workshop as industrial design workshop is a positive step.

Teachers offered various suggestions regarding the development of RiöLP's program, educators, the purpose of the education, methods of education, education environment and cooperation between institutions. Widely agreed suggestions are: offering the chance to attend classes from all main art branches/workshops, increasing workshop hours, not limiting secondary art branch choices, giving more importance to the art activities of academicians, focusing on the purpose of developing teachers and creating multi-dimensional individuals, using active learning methods, adding electronic devices/technology to workshops, and providing harmony between programs and cooperation between faculties and MEB (Ministry of National Education).

\section{Discussion, Conclusion \& Implementation}

It is known that art has enormous importance for the development of a society. Emphasis on art education is more than training new artists, it is based on teaching how to see more than how to look. Everyone can look but not everyone can see. As a result, it is extremely important to develop qualified teachers and graduate them with various perspectives. Results found out in this research show that RiÖLPs have many problems although they have a highly important role in training art educators. One of the problems we faced in this process is insufficient class hours. Although this is not an experience based research directly on ETE, the result is in harmony with Özsoy and Şahan (2009), Buyurgan (2007) and Kavuran (2003) studies where RiÖLPs are evaluated.

One of the most important results of this study is the opinion that Industrial Design Main Arts Branch has an important role in providing ETE qualification. Teachers argued that the existence of "Industrial Design" workshops in the general framework of "Art and Craft" cannot be denied, students are fascinated by three dimensional studies with various materials, they become more creative and more interested in learning, and this can easily be provided by teachers who gained ETE qualification. One of the results of the research shows that multidimensional education has a positive influence on creativity and it is in harmony with results found by Uysal (2005).

Art and Craft classes in primary and secondary schools now have a new name, "Visual Arts" and it covers a larger area. While the class gains a new name and covers a wider field, in RiöLP where the teachers of these classes are trained, there is still one field limit and only two extra workshops. That looks incoherent and results in professional inadequacy. Incoherence in these programs has been detected in Ayaydın's (2011) research as well. For that reason, there is a need to restructure the purpose and content of RiÖLP according to primary and secondary school programs.

While program classes and contents change, it is the education of teacher candidates and the workshops they attend that matters. It is critical that teacher candidates are aware of the importance of ETE professionally and also in our daily lives, while they are students. As Gökay Yılmaz (2009) suggests, we should be able to apply knowledge and skills in correct time and space. The Education System should give more importance to the creativity and skills of individuals in artistic fields. Teacher candidates should graduate as researcher-developer-creative-analytic individuals. The suggestions offered by teachers about RiÖLP, show that RiÖLPs need a general revision in the purpose of its programs, content, methods, education environments and academicians. For this reason, before all else, more comprehensive program evaluation studies are needed. 


\section{Resim-İ̧ Öğretmenliği Programlarının Öğretmen Adaylarına "Endüstriyel Tasarım Eğitimi” Yeterliği Kazandırma İşlevleri Açısından İncelenmesi*}

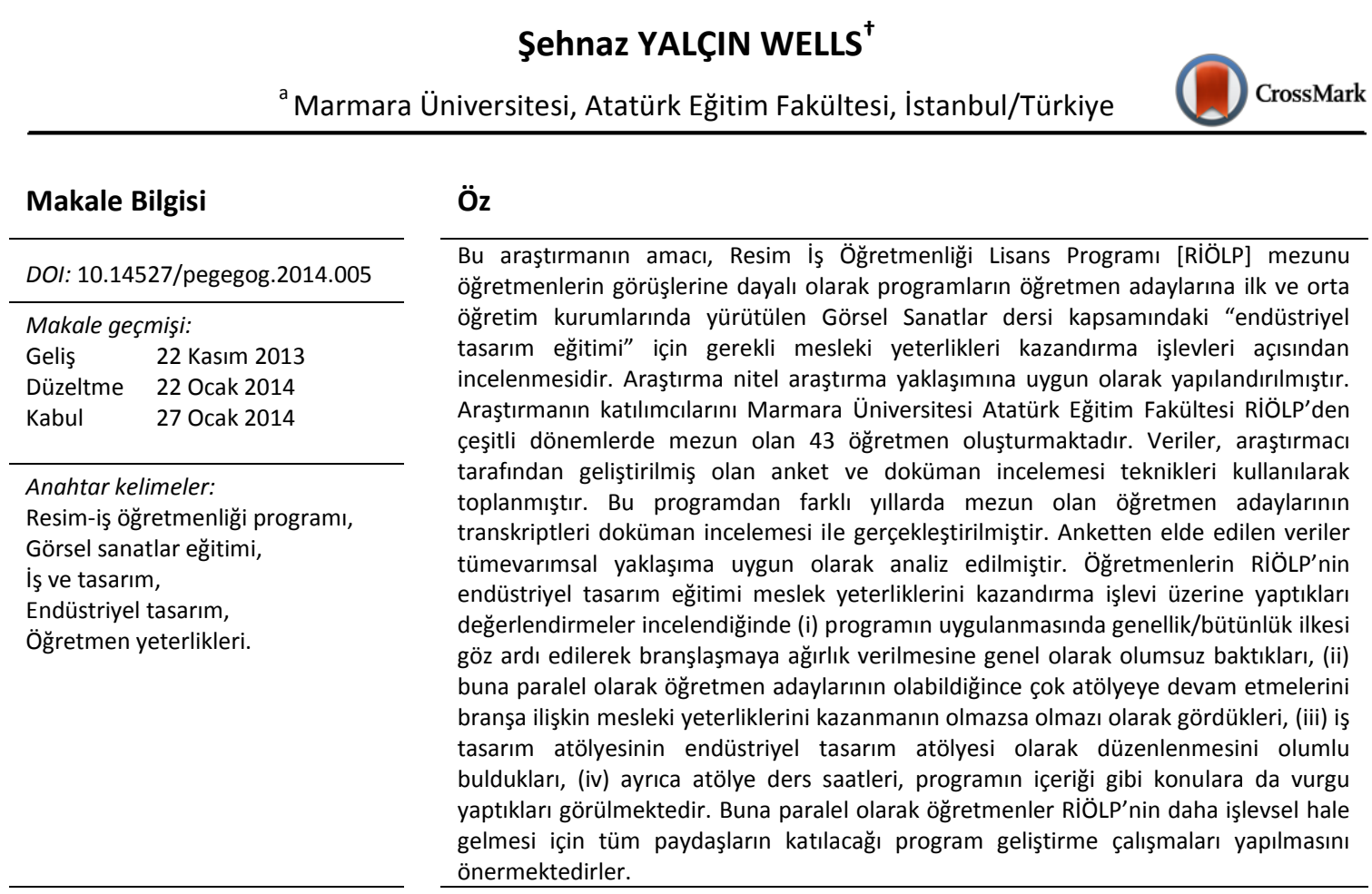

Giriş

Sanat eğitimi amaç, içerik ve yöntemi birçok faktörün etkisiyle sürekli olarak değişime uğramıştır. Bu faktörlerin başında sanat ve sanat eğitimine ilişkin paradigmalar gelmektedir. Günümüzde üzerinde büyük uzlaşı sağlanan sanat eğitimi kavramı "bireylerin sanat ve kültür alanlarında yetiştirilip, bilinçlendirilme çabası" (Uysal, 2005: 41) olarak tanımlanabilir. Buna paralel olarak sanat eğitimi “öğrencilerin estetik duyarlılığını geliştiren, kendi güçlerini ve önemli olacak görsel gerçekleri tanımalarında önderlik eden, düşünme güçlerini arttıran, sosyal çalışmaları olan ve yaratıcı bireylerin oluşmasını sağlayan bir eğitim sistemi" (Şahin, 1999 akt. Türe, 2007: 40) olarak da ifade edilebilir. Bu tanımlardan anlaşılacağı gibi sanat eğitiminin sağlıklı ve etkin bireyler yetiştirme ve toplumsal gelişmede çok önemli bir misyonu vardır. Kuramsal ve uygulamalı çalışmalarla verilen sanat eğitimi kimi zaman sadece plastik sanatları, kimi zaman da diğer sanat dallarını içerisine alır (Uysal, 2005).

Eğitim sistemimizde çocuklar ilkokul birinci sınıftan itibaren Görsel Sanatlar dersi sayesinde sanat eğitimi ile tanışmaktadırlar. Bu derse ilişkin algı, sanat eğitiminin kalitesinin de ipuçlarını vermektedir.

\footnotetext{
* Bu çalışma 5-7 Eylül 2013 tarihleri arasında Eskişehir Osmangazi Üniversitesi’nde düzenlenen 22. Ulusal Eğitim Bilimleri Kurultayı'nda sunulan sözlü bildirinin geliştirilmişş şeklidir.

†Yazar: sehnazwells@marmara.edu.tr
} 
Aynı konuların çizilip boyanmadığı, ezber yerine sorgulamanın, aktif katılımın ön planda olduğu bir Görsel Sanatlar programı etkin öğrenmeyi sunacaktır. Etkin öğrenme ile bilginin kalıcılığı sağlanacak; sanat, sanatçılar ve eserleri daha iyi tanınabilecektir (Gökay, 2009). Bu bilgiler günlük hayatla bağlantısı kurulabildiği sürece yerleşebilmektedir ve eğitim alan, sanat okuryazarlığı gelişen çocukta, çevresine bakış ve algılarındaki fark belirginleşecek, sanata bakış açısı gelişecektir.

Her çocuğun yaratıcılık anlatımında değişik yönleri bulunmaktadır ve burada çocuk kişiliği önemlidir. Kişilik, eğitim yılları boyunca çocuğun davranışlarını şekillendirmekteyken yaratıcı gücün nasıl korunacağı iyi bilinmelidir. Çocuğun, teknik ve hayal gücünü kullanmasına yardımcı olunmalı (Kehnemuyi, 2004), özgür ve yaratıcı bir birey olarak kalması sağlanmalıdır. Sanat eğitiminde çocuk kendi kişiliği ve eğilimleri doğrultusunda yönlendirilmeli, özgürce kendini ifade edebilme ortamı bulabilmelidir. Üreten, seçen, beğenen, kendini ifade edebilen birey, içinde yaşadığı toplumun bir üyesi, geleceğinin temsilcisidir (Buyurgan ve Buyurgan, 2012). Öğrencinin algısal tercihleri görsel, dokunsal, işitsel, kinestetik olabilirken aynı zamanda bilgiyi işlemedeki zihinsel süreçleri analitik, bütünleşik ve global olarak farklılaşabilmektedir. Bu öğrenme faktörlerini içeren öğrenme stilleri de önemlidir.

Günümüzde eğitim sisteminden beklenilen sadece bilgi kazandırılması değil, değişik sentezler, farklı fikirler, ürünler ortaya çıkarabilme yeteneğinin geliştirilmesi ve uygulanabilmesidir (Gökay, 2009). Yapılandırmacılık ve çoklu zekâ kuramlarına dayalı, çağdaş sanat eğitim yöntemlerini içeren ve sarmal yapıya göre tasarlanan Görsel Sanatlar dersi öğretim programı (Gökay, 2009), Millî Eğitim Bakanlığı [MEB] tarafından 2006 yılında yürürlüğe konmuştur (MEB, 2006a). Görsel Sanatlar dersine çoklu zeka kuramının taşınmasıyla daha zevkli hale geleceği de vurgulanmaktadır (Ayaydın, 2009). Bir öğretim alanı olarak görsel sanatlar eğitimi; dünden bugüne resim, resim-iş, iş bilgisi (MEB, 1992; MEB, 2000; MEB, 2006b; MEB, 2010; Peşkersoy ve Yıldırım, 2010) gibi adlar altında ilk ve ortaöğretim kurumları programlarında yer alan derslerin konu alanlarını kapsamaktadır (Kırışoğlu, 2009). Bu nedenle Görsel Sanatlar dersi Türkiye'deki yaklaşık yüz yıllık sanat ve iş eğitimi geleneği ile alana ilişkin çağdaş yönelimlerin buluşma noktasında yer almaktadır.

Nitelikli bir sanat eğitimi; sanat eğitiminin varlığının, öneminin farkında olan bir bakış açısı, çağın değişen ve gelişen şartlarına göre kendini yenileyen bir eğitim programı, nitelikli sanat eğitimcisi, yeterli ders saati, amaca uygun fiziki donanım ve araç-gereç ile gerçekleşir (Buyurgan ve Buyurgan, 2012). illk ve ortaöğretim resim-iş programında resim-iş derslerine daha uzun sürenin tanınması ve bu sürenin niteliği yönünde, resim-iş derslerinin ortam, materyal, araç ve gereç açısından daha donanımlı hale getirilmesi gerektiği (Özsoy ve Şahan, 2009) vurgulanmakla birlikte Buyurgan ve Buyurgan (2012)'ın da değindiği gibi nitelikli sanat eğitimcisinin ve güncel kalabilen eğitim programının rolü de oldukça önemlidir. Bu açıdan alan öğretmenlerinin yetiştirilme sistemi özellikle incelenmesi gereken konulardan birisini oluşturmaktadır.

\section{Problem}

Günümüzde Eğitim Fakültelerinde uygulanmakta olan Resim-Iş Öğretmenliği Lisans Programı [RiÖLP]'nın temel misyonu evrensel standartlarda sanat eğitimcileri yetiştirmektir. Türk eğitim sisteminde ilk ve orta öğretim kurumlarındaki öğretmen istihdam alanları açısından söylemek gerekirse, adı geçen programın amacı, ülkenin "Resim-Iş Öğretmeni” gereksinimini karşılamaktır. Eğitim fakülteleri lisans programlarının yeniden yapılanmasıyla birlikte resim-iş öğretmeni yetiştirme sisteminde de önemli değişiklikler meydana gelmiştir. YÖK tarafından hazırlatılan ve yürürlüğe konan RiÖLP'ler diğer öğretmen yetiştiren programlar gibi genel kültür, alan bilgisi ve meslek bilgisi derslerini kapsamaktadır. Alan Bilgisi öğretimi teorik dersler ile atölyelerde yapılan uygulamalı eğitim şeklinde sürdürülmektedir. RiÖLP'ler her ana bilim dalında dokuz atölye (dal) açılabilmesini öngörmektedir (YÖK, 1998). Her eğitim fakültesi olanakları dâhilinde tüm dalları faaliyete geçirmektedir. Bununla beraber, yürürlüğe girdiği tarihten itibaren genel olarak RiÖLP'nin beraberinde getirdiği amaç, kapsam ve eğitim durumu, özelde de öğrencilerin bu atölyelerde nasıl öğrenim görmeleri gerektiği konularında farklı görüşler ileri 
sürülmektedir. Bu görüşler iki grupta toplanabilir: (i) Öğrenciler asgari bir süre tüm atölyelerde öğrenim görmeli, ondan sonra Ana Sanat Atölyesini seçmelidir. Bu onlara sanat dalları/atölyeler arasında daha bilinçli bir tercih yapmayı sağlamanın yanı sıra bir öğretmende bulunması gereken farklı sanat dallarına ait bilgi ve becerileri de kazandıracaktır. (ii) Öğrencilerin tüm atölyelerde öğrenim görmeleri zaman kaybıdır; bu nedenle öğrenciler Ana Sanat Dallarının yanında sınırlı sayıda atölyeyi seçmelidir.

Bu iki görüş eğitim fakülteleri RiöLP'lerinin biçimlenmesinde belirleyici olmuştur. 1998 yılındaki yapılanma öncesi programlarda birinci görüş, bu tarihten sonraki programlarda ise ikinci görüş etkindir. Öyle ki 1998 öncesi dönemde öğretmen adayları ikinci sınıfta dönüşümlü olarak tüm atölyelere devam etmekte, üçüncü sınıfta branşlaşmaktaydı. Bu program tasarımı resim-iş öğretmenliği eğitiminin çok boyutluluğu açısından son derece önemliydi. Ancak RiÖLP'nin 1998 yılında yürürlüğe girmesinden sonra öğrenciler ikinci sınıfta branşlaşmış ve anasanat atölyesi haricinde zorunlu seçmeli kategorisinde iki atölyeye devam edebilir hale gelmiştir. Böylece öğretmen adayları resim-iş öğretmenliği meslek yeterliklerini kazandırmada rolleri tartışmasız olan sanat dallarıyla ilgili hiçbir eğitim almadan mezun olmaya başlamıştır.

Illköğretim ve ortaöğretim programlarını etkin bir şekilde uygulamak için gerekli meslek yeterliklerini kazandırma işlevi açısından bakıldığında RiöLP'nin sanat dalları/atölyeleri ile ilgili düzenlemenin, uygulama sahasında bazı önemli sorunlara yol açtığı ileri sürülmektedir. Bu görüşlerden birisi, 1998 programının Görsel Sanatlar dersi kapsamında yürütülen endüstriyel tasarım eğitimi [ETE] için gerekli yeterlikleri kazandırma yönünden geliştirilmeye intiyaç duyduğu yönündedir. ETE için gerekli yeterliklerin en etkili şekilde kazandırılabileceği atölye sayılabilecek endüstriyel tasarım anasanat atölyesi, RiöLP'nin yeniden yapılanmayla birlikte mevcut programda toplam altı dönem okutulmaktadır. İkinci veüçüncü sınıflarda haftalık iki saat teorik, dört saat uygulama olmak üzere toplam altı saat okutulan ders dördüncü sınıfta 4 saat teorik ve dört saat uygulama olmak üzere tüm anasanat atölyelerinde olduğu gibi toplamda sekiz saat olarak yer bulmaktadır. Atölyede bireysel ve grup çalışmaları şeklinde yapılan maket ve proje çalışmaları, işlevsellik yönü olan sanatsal işler halinde uygulanmakta ve endüstriyel tasarımın günlük yaşamdaki kullanım alanları üzerinde durulmaktadır. Endüstriyel tasarımı ana sanat atölye dersi olarak seçen öğrencilere, seçmeli sanat atölye derslerinin iki yarıyıllık kısmında resim atölye dersi zorunlu olarak seçtirilmektedir. Öğrencinin, diğer seçmeli sanat atölye derslerinden bölüm olanaklarına göre istediği atölye derslerini seçebilmesi öngörülmekte (YÖK, 1998) ve uygulanmakta olan programda ikinci sınıfta branşlaşan öğrenci ikinci ve üçüncü sınıfta zorunlu seçmeli resim dersini, dördüncü sınıfta ise farklı bir zorunlu seçmeli dersi almaktadır.

\section{Program değerlendirme açısından ilgili literatür}

Programların etkililiği genel amaçları doğrultusunda uygulamadan elde edilen dönütler ışı̆̆ında sürekli olarak geliştirilmesiyle sağlanabilir. Bundan dolayıdır ki program geliştirme "dinamik bir süreç" olarak nitelenmektedir. Program geliştirmenin ilk aşaması ise program değerlendirmedir (Demirel, 1997; Ertürk, 1993; Oliva, 2001; Varış, 1988). Maalesef merkezi yönetim tarafından hazırlanan eğitim fakülteleri lisans programları herhangi bir sistematik değerlendirmeye tabi tutulmadan yeterli olduğu varsayılarak yıllarca uygulanmaktadır. RiöLP'de gerçekleşen ve yukarıda özetlenmiş olan tüm bu değişiklikler çerçevesinde gelişen tartışmalar ve öğretmen eğitiminin işlevselliğine yönelik olarak getirilen eleştirilere rağmen, (a) Türkiye'de eğitim fakülteleri programları üzerine ulusal ölçekte program değerlendirme çalışması yapılmadığı, (b) bu programları değerlendirecek akreditasyon sistemi de kurulmadığı için, bu konuda elimizde yeterli bilimsel veri bulunmamaktadır. Bu nedenle araştırmacılar tarafından gerçekleştirilen ve çeşitli açılardan programların değerlendirilmesini amaçlayan çalışmalar büyük önem kazanmaktadır. Örneğin bu çalışmalardan birisinde Buyurgan (2007) resim iş öğretmenliği öğrencilerinin aldıkları eğitime ilişkin görüşlerini belirlemiştir. Kavuran (2003) ise Türkiye'deki RiöLP'lerin uygulanmasında karşılaşılan sorunları tespit etmiştir. Bu iki araştırmanın sonuçları ders saatlerinin arttıııması, öğretim elemanlarının kendilerini yenilemeleri, teknolojinin kullanımının geliştirilmesi gerekliliklerine işaret etmektedir. Ayaydın (2011) ise RiöLP'lerin ilköğretimdeki Görsel Sanatlar dersi 
öğretim programları ile bazı yönlerden uyum içinde olmadığı sonucuna ulaşmıştır. Genel olarak RiöLP'lerin değerlendirilmesini amaçlayan ve yukarıda sonuçlarına değinilen çalışmaların dışında gerçekleştirilen diğer bazı araştırmaların ise (Eldemir, 2011; Gökay-Yılmaz, 2009; Kiprik ve Şirin, 2012; Polat, 2013; Sarı, 2000) daha çok eğitim ve öğretim uygulamalarının bir boyutu, öğrenci seçme süreci, öğrenci tutumları, öğrenci başarısının yordayıcıları gibi spesifik konularla ya da bu alandaki araştırmaların meta analizi ile sınırlı olduğu görülmüştür. İlgili literatürde incelenen araştırmaların konularından da anlaşılacağı gibi bu araştırmalarda doğrudan ETE üzerine odaklanılmamış, Resim-iş öğretmenliği programlarının öğretmen adaylarına ETE yeterliliği kazandırma işlevlerinin ne kadar gerçekleştirildiği ve bu süreçte endüstriyel tasarım anasanat atölyesinin rolünün ne olduğu sorusu yeterince araştırılmamıştır. Endüstriyel Tasarım ders içeriği son derece verimlidir. Değişen programların olumlu katkılarının yanında eksik yönlerinin uygulamaya nasıl yansıdığının araştırılması, program değerlendirme çalışmaları, bundan sonraki program geliştirme, ders kitabı hazırlama ve öğretmen eğitimi uygulamaları bakımından önemlidir. Gelecekte daha etkin bir sanat/resim-iş eğitimi için bu tür çalışmalara dayalı zengin bir alan yazına ihtiyaç vardır.

\section{Araştırmanın Amacı}

Araştırmanın amacı, RiÖLP’lerin öğretmen adaylarına Görsel Sanatlar/Resim-İ̧ dersi kapsamında sürdürülen ETE için gerekli yeterlikleri kazandırma işlevlerini ne kadar ve ne şekilde gerçekleştirdiklerinin öğretmen görüşlerine göre saptanmasıdır. Bu amaç doğrultusunda aşağıdaki sorulara yanıt aranmıştır:

Resim-iş öğretmenliği lisans programı mezunu öğretmenlerin,

1. RiÖLP'nin öğretmen adaylarına ETE için gerekli yeterlikleri kazandırmadaki rolü konusundaki görüşleri nedir?

2. RiÖLP'de yapılan düzenlemeler ile ilgili görüşleri nelerdir?

3. RiöLP'ye ilişkin önerileri nelerdir?

\section{Sınırlılıklar}

Araştırmanın sınırlılıkları aşağıdaki gibidir:

1. Bu araştırmanın bulguları, katılımcıları oluşturan Marmara Üniversitesi Atatürk Eğitim Fakültesi Resim-İş Öğretmenliği Programı́ndan farklı yıllarda mezun olmuş 43 öğretmenden elde edilen verilerle sınırlıdır.

2. Araştırma, anket ve doküman analizi teknikleri ile toplanan verilerle sınırlıdır.

\section{Yöntem}

\section{Araştırma Modeli}

$\mathrm{Bu}$ araştırma nitel araştırma yaklaşımına uygun olarak tasarlanmıştır. Nitel araştırma, "gözlem, görüşme ve doküman analizi gibi nitel veri toplama yöntemlerinin kullanıldığı, algıların ve olayların doğal ortamda gerçekçi ve bütüncül bir biçimde ortaya konmasına yönelik nitel bir sürecin izlendiği araştırma" olarak tanımlanmaktadır (Yıldırım ve Şimşek, 2006: 39). Bu çalışmada öğretmenlerin, mezun oldukları lisans programlarının endüstriyel tasarım eğitimi konusundaki yeterliklerinin gelişmesi üzerindeki rolünü kendi algıları, ifadeleri ve yorumları çerçevesinde incelemek amaçlandığından nitel yaklaşım tercih edilmiştir.

\section{Katılımcılar}

Eğitim Fakülteleri Güzel Sanatlar Eğitimi Bölümü Resim-İ̧̧ Öğretmenliği Anabilim dallarında toplam dokuz ana sanat dalı mevcuttur. Mekan, öğretim elemanı gibi sınırlılıklar nedeniyle her fakülte bu dokuz ana sanat dalını açamamakta, sınırlı sayıda anasanat dalında eğitim vermektedir. Türkiye'deki üniversitelerin web sayfalarında yapılan genel bir inceleme, ana sanat dallarının hepsinin ya da çoğunun sadece birkaç üniversitede açık olduğunu göstermiştir. Marmara Üniversitesi Atatürk Eğitim Fakültesi 
Resim-Iş Öğretmenliği Anabilim Dalı da yeterli öğretim elemanı bulunmamasından dolayı açılamayan Geleneksel El Sanatları haricindeki diğer dalların (sekiz anasanat dalının) faal olduğu sınırlı sayıdaki kurumlardan birisi olduğu için bu araştırmanın katılımcıları olarak seçilmiştir. Bu çerçevede araştırmanın katılımcılarını Bayburt, Adana, Gebze ve İstanbul'da çeşitli ilçelerdeki devlet ve özel okullarda görev yapmakta olan Marmara Üniversitesi Atatürk Eğitim Fakültesi Resim-iş Öğretmenliğinin farklı anasanat dalları veya atölyelerinden mezun 43 öğretmen oluşturmaktadır. Katılımcılar gönüllülük esasına göre ve kolay erişilebilirlik durum örneklemesine göre seçilmişlerdir. Seçilme ölçütü Marmara Üniversitesi Atatürk Eğitim Fakültesi Resim-İ̧ öğretmenliği programından mezun ve ilkokul, ortaokul veya lisede Görsel Sanatlar ve/veya sanatla ilgili ders vermiş olmaktır. Katılımcıların demografik özelliklerine ilişkin bilgiler Tablo 1'de sunulmuştur.

Tablo 1.

Katılımcıların Demografik Özelliklerine Göre Dağılımları.

\begin{tabular}{|c|c|c|}
\hline Cinsiyet & $\mathbf{N}$ & $\%$ \\
\hline Kadın & 38 & 92 \\
\hline Erkek & 5 & 8 \\
\hline \multicolumn{3}{|l|}{ Mesleki Kıdem } \\
\hline $1-5 \mathrm{yll}$ & 21 & 49 \\
\hline $6-10$ yıl & 9 & 21 \\
\hline $11-15 \mathrm{yll}$ & 2 & 5 \\
\hline $16-20 \mathrm{yıl}$ & 5 & 11 \\
\hline 21 yıl ve üstü & 6 & 14 \\
\hline \multicolumn{3}{|c|}{ Mezun olunan program dönemi } \\
\hline 1998 öncesi & 15 & 35 \\
\hline 1998 sonrası & 28 & 65 \\
\hline \multicolumn{3}{|c|}{ Mezun olunan ana sanat dalı ya da atölye } \\
\hline Endüstriyel Tasarım & 10 & 23 \\
\hline Resim & 10 & 23 \\
\hline Tekstil & 10 & 23 \\
\hline Grafik & 7 & 16 \\
\hline Fotoğraf & 3 & 7 \\
\hline Seramik & 1 & 3 \\
\hline Heykel & 1 & 3 \\
\hline Özgün Baskı & 1 & 3 \\
\hline \multicolumn{3}{|c|}{ En son görev yapılan eğitim kademesi } \\
\hline ilkokul & 16 & 37 \\
\hline Ortaokul & 19 & 44 \\
\hline Lise & 8 & 19 \\
\hline \multicolumn{3}{|c|}{ Görev yapılan okulun statüsü } \\
\hline Devlet okulu & 17 & 40 \\
\hline Özel okul & 26 & 60 \\
\hline Toplam & 43 & 100 \\
\hline
\end{tabular}

Tablo 1'e göre araştırmaya katılan öğretmenlerin \% 92'si kadın, \% 8'i ise erkektir. Öğretmenlerin neredeyse yarısının (\% 49) 1-5 yıl arasında mesleki kıdeme sahip olduğunu, yani katılımcıların önemli bir bölümünün mesleğinde yeni sayılabilecek öğretmenlerden oluştuğunu ortaya koymaktadır. Tabloya göre öğretmenlerin \% 65’i 1998 sonrası programdan mezun olmuştur. Araştırmaya katılan öğretmenlerin en 
yüksek ve birbirine eşit oranda (\% 23) endüstriyel tasarım, resim ve tekstil anasaat dallarından mezun oldukları görülmektedir. Öğretmenlerin en yüksek miktarının ortaokullarda (\% 44) görev ve özel okullarda (\% 60) görev yaptığı anlaşılmaktadır.

\section{Veri Toplama Aracı}

Araştırmada veriler anket ve doküman analizi teknikleri kullanılarak toplanmışır. Öğretmenlerin RiÖLP'lerin öğretmen adaylarına ETE yeterliliği kazandırma işlevlerini nasıl ve ne kadar gerçekleştirdiğine ilişkin görüşlerini belirlemek amacıyla anket formu kullanıımıştır. Araştırmacı tarafından geliştirilen anket, açık ve kapalı uçlu 5 demografik bilgi sorusu ile araştırma problemine ilişkin 14 açık uçlu sorudan oluşmaktadır. Anketin geliştirilmesi sırasında uzmanların görüşü alınmış, ankete son şekli bu değerlendirmeler ışı̆̆ında verilmiştir. Doküman analizi ise aynı fakültenin resim iş öğretmenliği lisans programından çeşitli dönemlerde (...-1985, 1984-1988, 1985-1989, 1986-1990, 1988-1992, 1987-1994, 1997-2001, 2001-2005, 2007-2012) mezun olmuş 9 öğrencinin transkriptleri üzerinde gerçekleştirilmiştir. 1985 ile 2012 yılları arasında belirli aralıklarla seçilmeye çalışılan bu transkriptlerin analizinde ilgili dönemde programda yer alan dersler, ders süreleri, alınan atölye çeşitliliği konularında incelemeler yapılarak dönemler arasındaki farklılaşmalar incelenmiştir.

\section{Verilerin Toplanması}

Veriler 2012-2013 eğitim öğretim yılı içerisinde toplanmıştır. Anketler öğretmenlere İnternet aracılı̆̆ı ile ulaştırılmıştır.

\section{Verilerin Analizi}

Toplanan veriler nitel içerik analizine uygun olarak tümevarımsal bir yaklaşımla analiz edilmiştir. Bu süreç "kodlama yoluyla verilerin altında yatan kavramları ve bu kavramlar arasındaki ilişkileri ortaya çıkarma” yı amaçlamaktadır (Yıldırım ve Şimşek, 2006: 227). Bu çalışmada RiöLP'lerin öğretmen adaylarına ETE yeterliklerini kazandırma konusundaki görüşlerinin nasıl bir örüntü oluşturduğu irdelendiğinden bu yaklaşım tercih edilmiştir. Araşsırma verilerinin analizi sürecinde öncelikle öğretmenlerden alınan yanıtlar analiz için düzenlenmiş ve analize uygun hale getirilmiştir. Daha sonra tüm veri setinden açık kodlama işlemi yapılmıştır. Verilerden yola çıkarılan kavramlara göre kodlama (Yıldırım ve Şimşek, 2006: 232) ya da açık kodlama olarak adlandırılan bu kodlama şeklinde yapılan analizin devamında ulaşılan kodlar arasında çeşitli bağlantılar kurularak kategorilere ve temalara ulaşılmıştır. Sonrasında veriler kodlara ve temalara göre düzenlenmiş, ilgili bölümlerde kullanılan alıntılar seçilmiş ve bulgular yazılmışır.

Araştırmada ulaşılan verilerin güvenilebilirliğini sağlamanın yollarından birisi farklı veri toplama teknikleri kullanmaktır. Bu çalışmada dönemler arasında karşılaştırma yapılabilmesi için ayrıca doküman analizi tekniği işe koşulmuştur. Açık uçlu sorulardan elde edilen nitel veriler iki araştırmacı tarafından kodlanmıştır. Kodlamalar arasındaki uygunluğun belirlenmesi için Miles ve Huberman (1994) formülü kullanılmıştır. Bu süreçte iki araştırmacının yaptığı kodlamalarda görüş birliği sağlanan ve görüş ayrılı̆̆ı oluşan kodlar belirlenmiş, formül yardımıyla güvenirlik hesaplaması yapılmıştır. Yapılan hesaplama sonunda \% 86 oranında uygunluk tespit edilmiştir. Bu oranın \% 70'in üzerinde çıkması analizin güvenilir olduğunu göstermektedir. Bununla birlikte araştırmaya internet yoluyla katılan öğretmenlerin verdikleri yanıtların netliği konusunda tereddüt yaşandığında ifadelerinin anlamı ve netleştirilmesi konusunda zaman zaman teyitler alınmıştır. Ayrıca araştırmanın inandırıcılığı ve güvenirliği için araştırmada ulaşılan bulgular katılımcıların kendi ifadelerinden yapılan doğrudan alıntılarla desteklenmiştir. Bulgular sunulurken katııımcılardan yapılan doğrudan alıntılarda erkek katılımcılar için EÖ (Erkek Öğretmen), kadın katıııcılar için ise KÖ (Kadın Öğretmen) kodlamaları kullanılmış ve katılımcı numaraları parantez içerisinde belirtilmiştir. Transkriptlere atıf yapılırken her bir transkripte bir kod verilmiş, devamında öğrencinin mezuniyet yılı belirtilmiştir. 


\section{Bulgular}

RiÖLP'nin öğretmen adaylarına "endüstriyel tasarım eğitimi” yeterliği kazandırma işlevlerini ne kadar ve ne şekilde gerçekleştirdiğinin araştırıldığı bu çalışmada üç temaya ulaşılmış, bulgular bu temalar, kategoriler ve kodlar çerçevesinde sunulmuştur.

\section{RiöLP'nin ETE Yeterliklerini Kazandırmadaki Rolü}

Öğretmenlerin, RiöLP’nin öğretmen adaylarına ETE için gerekli yeterlikleri kazandırmadaki rolü konusundaki görüşlerine ait atölye çeşitliliği, atölye ders saatleri ve programın içeriği kategorilerine ulaşılmış, bulgular bu çerçevede sunulmuştur.

\section{Atölye çeşitliliği}

Araştırmaya katılan öğretmenlerden 41'i, RiöLP sırasında farklı sanat dalları/atölyeden ders almanın sanat eğitimcisi olarak öğretmen adaylarının mesleki gelişimlerine olumlu katkısı olduğu yönünde görüş belirtmişlerdir. Belirtilen bu olumlu görüşlerin nedenlerine ilişkin yapılan atıflardan elde edilen kodlar Tablo 2'te sunulmuştur.

\section{Tablo 2.}

Atölye Çeşitliliği Kategorisine Ait Kodlar.

\begin{tabular}{lr}
\hline Kodlar & $\mathbf{f}$ \\
\hline Mesleki donanım sağlaması & 24 \\
Yetkinleşme sağlaması & 4 \\
Öğretmenlik mesleği için temel oluşturması & 9 \\
Nitelikli öğretmen yetiştirilmesini sağlaması & 16 \\
Yıllık planlardaki konuların zenginleştirilmesi & 19 \\
Öğretmenin öğrencilerin bireysel farklılıklarını keşfetmesine imkan sağlaması & 3 \\
Her alan/branşta/ASA da bilgi sahibi olmayı sağlaması & 33 \\
Doğru/uygun alanı seçme/keşfetme imkanı bulması & 5 \\
Yaratıcılığı desteklemesi & 4 \\
Sanat eğitimine zenginlik katması & 3 \\
Malzeme bilgisi sağlaması & 14 \\
\hline
\end{tabular}

Atölye çeşitliliği konusundaki kodlar incelendiğinde öğretmenlerin, farklı atölyelerden ders alınmasının mesleki donanımı sağladığı, öğretmenlik mesleği için temel oluşturduğu, yetkinleşmeyi sağladığı ve dolayısıyla da nitelikli öğretmen eğitimine katkıda bulunduğunu dile getirdikleri görülmektedir. Örneğin EÖ(15) bu konudaki düşüncelerini "Bizler her dalı bir dönem görerek tam bir öğretmen olma donanımı ile yetiştirildik. ...Her dersin çok faydasını görmekteyim. Bir sanat öğretmeninin de her alanda fikir sahibi olması önce kendisi için, sonra sanatı sevdirmeye çalıştığı öğrencileri için mutlak gerekliliğine inanıyorum." sözleriyle dile getirirken KÖ(32) ise "Üniversiteden mezun bir resim öğretmeni mesleğinin her branşında donanımlı, yeterli bir şekilde mezun olmalıdır ki gelecek nesillere de faydalı olabilsin" şeklinde ifade etmiştir. KÖ(9) ise bu yöndeki eğitimin mesleki yeterliğine katkısını "Mesleki açıdan diğer dalları da gördüğüm için, birey olarak kendimi daha yeterli hissetmeme yardımcı oldu." ifadeleriyle ortaya koymuştur. KÖ(20) ise bu konudaki arzusunu şöyle dile getirmiştir:

"Farklı sanat dallarından eğitim almamı tabi ki mesleki gelişimimize çok büyük katkıda bulunmaktadır. Çok farklı dersler ve içerikleri her sanat dalı hakkında en azından birkaç bilgiye sahip olmamız konusunda oldukça faydalıdır. Eğitim verdiğimiz kurumlarda ise her ders içeriği hakkında bilgilere sahip olmamı sağlamıştır. Olumlu yanları gerçekten fazla, keşke daha çok sanat dalını ders olarak görebilseydik bu şekilde daha kesin bilgilere ulaşırdık." 
Öğretmenlerin atölye çeşitliliği konusunda vurguladıkları temel katkılardan birisi de bu şekilde çok yönlü olarak gerçekleşen eğitimin yıllık planlarındaki etkinliklerini zenginleştirmelerine ve öğrencilerinin bireysel farklılıklarını keşfetmelerine imkan tanıdığı ve bu nedenle sanat eğitimine zenginlik kattığı yönündedir. Örneğin KÖ(39) farkıı atölyelerden ders almanın bir öğretmen olarak kendisine sağladığı yararları şöyle sırlamıştır: "Görsel Sanatlar öğretmeni olarak güzel sanatların her alanında bilgi sahibi olmak, yetkin olmak istediğin alanı daha iyi seçme imkânı bulmak, farklı branşlardaki öğrenme ve öğretme teknikleri ile yaratıcı çalışmalar-planlar hazırlamak, disiplinler arası çalışmalar ile projeler hazırlamak, müfredatta işlediğim yatay ve dikey ders planlarına entegre olmak.". Bu şekilde düşünen öğretmenler genellikle bu yöndeki eğitimin kendi öğrencilerine katkııın vurgulamışlardır. Örneğin KÖ(21) "Kesinlikle farklı atölyelerde çalışmak çok şeyler katmaktadır. Görsel Sanatlar kapsamı geniş olduğundan öğretmenin donanımı açısından ne kadar farklı atölyelerde çalışırsa o kadar dersi zevkli hale getirir... ve çalışma yelpazesi genişler... Öğrencilerine de çok şeyler katar." şeklindeki sözleriyle bu zenginliğin öğrenciye yansımaları üzerine düşünce belirtmektedir. Benzer yönde görüşlere sahip bazı öğretmenlerin ifadeleri aşağıda sunulmuştur:

KÖ(19): "... Vizyonum artmıştır, sanatın her daldan faydalanarak öğrencilerimin hayal gücünü genişletmeme faydası olmuştur."

EÖ(37): "Bu alan eğitimlerini alan öğretmeler çok daha meraklı olur, inceler, gözler, yeni ve gelişen değişken malzemeleri takip eder, araştırır- uygular. Bu da yeniliği, farklılı̆ı, üslubu geliştirir. Farklı sanat disiplinleri ortaya çıkarır ve öğrencilerini yönlendirir. Yaşadığı sosyal ekonomik çevrenin verdiği imkanlar içerisinde yaşayabilecek problemlerle alternatif çözümler üretebilme yetileri gelişir. Bu almış olduğu sanat eğitimi alanlarının vermiş olduğu bir cesarettir."

Öğretmenlerin atölye çeşitliliği konusunda olumlu olarak değerlendirdikleri bir başka konu ise farklı atölyelerde eğitim almanın yaratıcılık üzerinde önemli etkiye sahip olduğu şeklindedir. Örneğin KÖ(10) farklı atölyelerden ders alarak öğrenilen tekniklerin hem öğretmen adayının yaratıcılı̆ı hem de öğretmenlik mesleği üzerindeki olumu etkisini "Olumlu yönü açısından bakacak olursak farklı tekniklerin öğrenilmesi aday öğretmenin yaratıcıı̆̆ına katkı sağlayacağı gibi öğrencilere sunulan verimi de arttıracak ve aday öğretmenlerin farkı teknikleri öğrencilerle paylaşmaları ve uygulatmaları ile öğrencilerin sanata karşı ilgileri artacaktır." sözleriyle dile getirmiştir. Aynı yöndeki katkıya EÖ(7) "Bilgime bilgi kattı, uygulama alanımda ise sürekli yaratıcı ruhumu ayakta tuttu." sözleriyle dikkat çekmektedir. EÖ(15) ise bu şekilde aldığı eğitimin kendi öğrencileri üzerindeki etkisine şöyle değinmiştir: "Zaten sanat eğitimi salt boya-kâğıt ve kalemden ibaret değildir. Öğrenci farklı malzemelerle duygularını dışa nasıl vuruyor? yaratıcılığını nasıl değerlendiriyor ve elbette ki en önemlisi bundan nasıl keyif alıyor? bunlar çok önemli, bir resim yapmakla beraber farklı materyallerden yararlanıyor olmak kuşkusuz ki, çocuğun iç dünyasında yeni kapılar açıyordur, artık günümüz çağdaş sanatında resim sadece boya ve tuvalden ibaret değildir." Atölye çeşitliliği konusunda dile getirilen bir başka husus öğretmenlerin malzeme bilgisi açısından sağladıkları kazanımdır.

KÖ(3): "Diğer dallarda farklı malzeme bilgisi veriliyor ve edinilen her bilgi aslında bir değer katıyor kişilere."

KÖ(13): "Bir defa malzemeyle sürekli içli dışlısınız malzemeyi iyi tanıyorsunuz ne yapacağınız ve neyi hangi yöntemle yapacağınız konusunda bilginiz var. Çok yönlü olmak her zaman mesleğimizde varolmuştur. Resim iş öğretmenliği sadece resim tekniğini vermiyor öğrenciye iş yeteneğini de sunuyor. Unutmayın ki bütün sanat dalları birbirleriyle ilintilidir ve tamamlayıcıdır."

Transkript incelemelerinden elde edilen bulgular, RiöLP'de yer alabilen dalların büyük bir çoğunluğunun 1998 öncesi dönemde 2. sınıfta alınıp 3. sınıfta dallara ayrılmaları ve daha önceki dönemlerdeki programlarda ise farklılıkların olduğunu göstermektedir. Transkriptlere göre 1985 döneminde (M.Y. 1985) az da olsa farklı dalların eğitimi mevcutken (M.G. 1989; A.D. 1988) 1988, 1989 mezunlarında günümüzdeki gibi tek dal ve yan sınırlı dal sayıları dikkat çekicidir. Bu durum, yan dalıyla birlikte tek dal seçmeli uygulamasının daha önceden de (belki de imkansızlıklar dahilinde) denenmiş olduğunu ve sonrasında dallarda/atölyelerde çoğaltılmaya/zenginleştirmeye/donanıma gidildiğini 
göstermektedir. 1998 sonrasında ise atölye derslerinin tümünü göremeyen öğretmenler yetişmeye başlamıştır.

\section{Atölye ders saatleri}

Ankette öğretmenlerden ETE yeterliklerini kazandırması açısından RiÖLP’yi ders saatleri konusunda değerlendirmeleri istenmiştir. Öğretmenlerin bu konu hakkındaki düşünceleri atölye sürelerinin yeterli olup olmamasına göre iki kategoride değerlendirilmiştir. Bu konuda ulaşılan bulgular Tablo 3'te sunulmuştur.

Tablo 3.

Öğretmenlerin Atölye Ders Saatlerine Ilişkin Genel Görüşleri.

\begin{tabular}{lrr}
\hline Görüşler & f & \% \\
\hline Yeterli & 12 & 28 \\
Yeterli değil & 31 & 72 \\
\hline
\end{tabular}

Tablo 3'ten öğretmenlerin 31'inin (\%72) atölye ders saatlerini yetersiz olarak değerlendirdikleri, 12 'sinin (\%28) ise yeterli olarak değerlendirdikleri görülmektedir. Ders ve atölye saatlerinin yetersizliği konusunda görüş bildiren öğretmenlerin, yaşanan bu süre yetersizliklerinden kaynaklanan bazı sorunlara değindikleri görülmüştür. Ders sürelerinin yetersiz olduğunu düşünen öğretmenlerin bu konudaki yargılarını temellendirirken dile getirdikleri ifadelerin analizi sonucunda ulaşılan kodlar Tablo 4'te sunulmuştur.

Tablo 4.

Atölye Ders Saatleri Kategorisine Ait Kodlar.

\begin{tabular}{ll}
\hline Kodlar & $\mathbf{f}$ \\
\hline Eğitimin sıkıştırılması & 4 \\
Pratik yapma imkanının olmaması & 3 \\
Ürün oluşturmaya/uygulamaya süre yetmemesi & 8 \\
Verimin düşmesi & 3 \\
Sanat eğitiminin sınırlı kalması & 5 \\
\hline
\end{tabular}

Atölye ders sürelerinin yetersiz olduğu yönünde görüş belirten öğretmenler, ders sürelerinin yetersizliğinin genel olarak eğitimin kalitesinin düşmesi ve beklenen verimin gerçekleşmemesi sonucunu doğurduğunu dile getirmişlerdir. Örneğin KÖ (13) "Haftada altı saat aldığımız atölye eğitimini sıkıştırılmış ve yetersiz buluyorum. Kaldı ki bunu teknik bilginiz, pratiğiniz, yoksa bilgi anlatımı konusunda eksik kalabiliyorsunuz. Teknik bilgiyi kısa süreye sıkıştırılmış programlarla değil, dört yıl içerisinde farklı atölyelerden ders vererek daha verimli olunabilir." şeklindeki sözleriyle eğitimin sıkıştırılması, pratik yapmaya imkan kalmaması, sanat eğitiminin sınırlı kalması, ürün oluşturmaya sürenin yetmemesi, verimin düşmesi gibi sorunlara değinmiştir. KÖ(38), süre yetersizliği ve kapsamlı tasarım eğitiminin yetersizliğine "Bence alanı ne olursa olsun "tasarım" geniş kapsamlı incelenmesi gereken bir konudur. Bu konuda toplumu etkileyebilecek bir yetkinlik kazanabilmek için yeterli bir tasarım eğitimi aldığımızı düşünmüyorum. Ders saatleri mutlaka yeterli seviyeye getirilmelidir." şeklindeki sözleriyle birlikte değinirken $K O ̈(21)$ de süre yetersizliğinden verimin düşmesi ve ürün oluşturmaya süre yetmemesi açılarından yakınmaktadır:

KÖ(21): "Derse ayrılan süreyi yeterli bulmuyorum; uygulama dersleri açısından öğrencilere konuyu öğretirken derse ayrılan belli bir süreden sonra, uygulama aşamasında öğrenciye kalan süre öğrencinin kendini ve tasarlamak istediği ürüne yeterli süre kalmadığından ürünü oluşturmada süre yetmemektir... bu da öğrencinin ister istemez verimini düşürecektir."

Transkriptlerin analizi sonucunda da atölye süreleri ile ilgili bazı bulgulara ulaşılmıştır. YÖK tarafından uygulamaya konulan 1998 RiöLP incelendiğinde endüstriyel tasarım atölyesinde 1-6 olmak üzere toplam 
6 dersin yürütüldüğü görülmektedir (YÖK, 1998; E.C., 2005; Ç.Ş., 2012). Öğrenci transkriptlerinden 1998 'den önceki yıllarda iş̧ ve Tasarım adıyla aynı sayıda dersin yürütüldüğü bulgulanmaktadır (S.T., 1992; T.K., 1990; Y.G. 1994). Görüldüğü ders sayısı bakımından iki dönem arasında bir fark bulunmamaktadır. Fakat 1998 öncesi dönemlerde anasanat dalı haricinde branşı ile ilgili dalına bağlı ek dersler bulunmakta idi. Böylece anadalında öğrenci daha fazla ders görebilmekteydi (A.A. 2001). Yani anasanat dalını destekleyen derslerde mesela bir tekstil tasarım öğrencisi dalıyla ilgili tekstil konstrüksiyon, tekstil teknolojisi, tekstil halk sanatları da almaktaydı veya bir iş ve tasarım öğrencisi anadalıyla ilgili form-inşa dersi görebilmekteydi. Sonuçta, 1998 öncesi ve sonrasında anadallar/atölyelerin ders sayısı eşit gibi görünse de dal/atölye kapsamı dahilindeki derslerle ders sayıları dönemlerde 1998'in hemen öncesinde daha fazlaydı.

1998 öncesi anasanat dalı, sonrasında ise anasanat atölyesi olan dersler ders saatleri açısından önemli bir fark içermektedir. 1998 öncesi programda değişik dönemler içerse de anasanat dalında 12 saatlik ders süreleri (A.A. 2001) dikkat çekerken 1998 sonrasında ders süresi 6 saate düşmektedir (E.C. 2005; Ç.Ş. 2012). 1998 öncesi örneğin 1997 girişli bir tekstil anasanat dalı öğrencisi 2. sınıfta 3 saat, 3 ve 4. sınıf anasanat dalı olan tekstil tasarım 12 saat, dalıyla ilgili tekstil konstrüksiyon, tekstil teknolojisi, tekstil halk sanatları 8 saat yani yan dersleriyle toplamda 3 ve 4 . sınıflarda 20 saati bulan dal şimdiki adıyla anasanat atölye ders süreleri bulunmaktaydı (A.A. 2001). Günümüzde ise en son düzenlemelerde anasanat atölyeleri 2 ve 3 . sınıfta 6 saatken 4 . sınıfta 8 saatlik ders süresine çekilmiştir.

\section{RiöLP içeriği}

Öğretmenlerin RiÖLP içeriğinin, ETE için gerekli yeterlikleri kazandırma konusundaki rolüne ilişkin görüşleri üç alt kategori altında incelenmiş̧ir.

\section{RiöLP atölyelerinin işlevselliği}

Ankette, öğretmenlerden resim iş öğretmenliği lisans programında yer alan atölyeleri Görsel Sanatlar dersine katkısı açısından önem sırasına göre sıralamaları istenmiştir. Öğretmenlerin en önemliden önemsize doğru yaptıkları sıralamada ilk üç sırada verdikleri yanıtlar incelenmiş, sıralamaya ilişkin ulaşılan bulgular Tablo 5'te sunulmuştur.

Tablo 5.

Öğretmenlerin RiÖLP Atölyelerine ilişkin Işlevsellik Sıralamaları.

\begin{tabular}{lcccr}
\hline \multirow{2}{*}{ Anasanat dalları } & 1. sıra & 2. sıra & 3. sıra & \multirow{2}{*}{ Toplam } \\
\cline { 2 - 4 } & f & f & f & 35 \\
Endüstriyel Tasarım & 23 & 11 & 1 & 23 \\
Resim & 13 & 7 & 3 & 14 \\
Tekstil & - & 5 & 9 & 14 \\
Heykel & - & 7 & 7 & 11 \\
Seramik & 2 & 3 & 6 & 7 \\
Grafik & 1 & 3 & 3 & 4 \\
Özgün Baskı & - & - & 4 & 3 \\
Fotoğraf & - & 2 & 1 & 1 \\
Geleneksel Türk sanatı & - & - & 1 & \\
\hline
\end{tabular}

Tablo 5 incelendiğinde, öğretmenlerin Görsel Sanatlar dersine katkısı açısından endüstriyel tasarım atölyesini diğer atölyelere göre daha işlevsel buldukları anlaşılmaktadır. 23 öğretmen, endüstriyel tasarım atölyesini, işlevsellik açııından ilk sırada göstermişken, 11 öğretmen ikinci sırada göstermiştir. Bu iki frekans da kendi sırlamasında en yüksek değere sahip frekanslardır. Endüstriyel tasarım atölyesini izleyen ikinci sıradaki atölyenin ise ilk üç sırada toplam 23 kez belirtilen Resim atölyesi olduğu 
görülmektedir. Bu sonuç öğretmenlerin gerekli yeterliklerin kazandırılması konusunda endüstriyel tasarım atölyesine büyük bir önem atfettiklerinin bir göstergesi olarak değerlendirilebilir.

\section{Endüstriyel tasarım anasanat atölyesinin katkıları}

Öğretmenler, bir önceki kategoride ulaşılan bulgularla tutarlı olarak endüstriyel tasarım atölyesinin çeşitli katkılarını dile getirmişlerdir. Bu atölyenin katkıları konusunda ulaşılan kodlar Tablo 6’da sunulmuştur.

Öğretmenlerin genel olarak endüstriyel tasarım atölyesini işlevsel ve yararlı olarak değerlendirdikleri bir önceki kategoriye ait bulgulardan ve Tablo 6'daki kodlardan anlaşılmaktadır. Örneğin KÖ(9) "konuların öğretimi ve dersin işleyişi bakımından Endüstriyel Tasarım dersi tartışılamayacak kadar önemlidir" şeklindeki sözleriyle atölyenin önemine çarpıcı bir şekilde vurgu yapmıştır. KÖ(22) de bu atölyenin meslek yaşamındaki önemine "Tekstil Tasarım anasanat dalından mezun olmama karşın çoğunlukla Endüstriyel Tasarım Dersi'nin malzeme bilgisinden faydalandığımı söyleyebilirim." sözleriyle dikkat çekmektedir.

Tablo 6.

Endüstriyel Tasarım Anasanat Atölyesinin Katkıları Kategorisine Ait Kodlar.

\begin{tabular}{lr}
\hline Kodlar & $\mathbf{f}$ \\
\hline Malzeme bilgi ve farkındalığının artması & 33 \\
İlgi ve isteğin artması & 15 \\
Yaratıcılığın gelişmesi & 10 \\
Farklı çalışmalara imkan vermesi & 9 \\
Motor/el becerilerinin gelişmesi & 11 \\
Üç boyutlu düşünebilme ve üretme imkanı vermesi & 11 \\
Farklı bakış açısı gelişmesi & 6 \\
Zekanın gelişmesi & 2 \\
Verimliliğin artması & 6 \\
Öğrencinin kendisini tanımasına imkan vermesi & 2 \\
Grup çalışmalarına imkan vermesi & 2 \\
Araştırıp öğrenmeye teşvik etmesi & 7 \\
Çok yönlü olmayı sağlaması & 3 \\
Psikolojik gelişime destek vermesi & 1 \\
Sahne dekoru hazırlamada destek olması & 2 \\
Özgüveni geliştirmesi & 2 \\
\hline
\end{tabular}

Tablo 6'daki kodlar incelendiğinde, öğretmenlerin, malzeme bilgisinin ve kullanımının gelişmesini endüstriyel tasarım atölyesinin yararları konusunda ilk sırada gösterdikleri anlaşılmaktadır. Bazı öğretmenler bu alandaki eğitimin kendi bilgilerine katkısını dile getirirken bazı öğretmenler ise öğrencilerinin gelişimine katkıları açısından değerlendirme yapmışlardır. Örneğin KÖ(9), “Endüstriyel tasarım sayesinde resim dersi çocuklar için artık sadece resim defterinden ibaret değil. Malzemelerin sonsuz ve hepsinin amacına uygun ve amacı dışında kullanılabilirlik taşıdığını öğreniyorlar." sözleriyle öğrencilerinin kazanımına dikkat çekerken KÖ(22) bu atölyenin öğretmen adayına katkısını "Endüstriyel Tasarım anasanat dalı diğer anasanat dallarına göre daha fazla malzeme bilgisini içerisinde barındırmaktadır. Bu durumda bir öğretmen adayı en çok malzeme bilgisini buradan almaktadır." sözleriyle ifade etmiştir. Malzeme bilgisinin gelişmesi konusuna değinen bazı öğretmenlerin ifadelerinden örnekler aşağıda sunulmuştur:

KÖ(30): "Faydası çok büyük. Materyalleri kullanmayı ve farklı şekillerde değerlendirmeyi sağlıyor."

KÖ(34): "Endüstriyel Tasarım Derslerine girmememe rağmen ders aralarında göz gezdirdiğimiz bir atölyeydi entas atölyesi. Bence malzeme bilgisi olarak çok faydalı bir bölüm. Bir öğretmenin malzeme 
bilmesi çok önemli bence çünkü farklılığı kullandığı malzemelerde daha etkili gösterebilir öğrencilerine."

Öğretmenlerin bu atölyenin katkıları konusunda dile getirdikleri bir diğer nokta bu tür çalışmaların öğrencilerde daha çok öğrenme isteği ve ilgisi uyandırdığı ve keyifli bir ortam sağladığı, sonuç olaraksa daha verimli bir öğrenme gerçekleştiği yönündedir. Bu konuya dikkat çeken öğretmenlerin birisi olan KÖ(29), "Öğretmenlerin değişik materyalleri derslerinde kullanmaları öğrencilerde de ilgi ve istek uyandırıyor. Bu da dersin daha verimli geçmesini sağlıyor." sözleriyle bu durumu doğrudan dile getirmiştir. KÖ(17) de bu konuda benzer düşünceyi "ilköğretimde daha basite indirgenerek işlendiğinde.1. ve 2.kademede en önemli atölyenin yeni adı End. Tas. atölyesi olduğunu düşünüyorum. Öğrenci sıkılmıyor ve ayrıca grup çalışmalarına uygun ve heycan verici oluyor." sözleriyle ifade etmiştir. Öğretmenler yaratıcılığın ve zekanın gelişmesini, bu atölyenin diğer önemli katkılarından ikisi olarak dile getirmişlerdir. Bu iki katkının örneğin KÖ(2)'nin “Çocukların yaratıcı zekalarını geliştirdiği için son derece yararlı olduğunu düşünüyorum. Görsel-uzamsal anlamda gerek ilkokul gerekse ortaokul çağındaki bireylerin zekalarını ve yaratıcılıklarını geliştiren bir ders olduğundan faydalıdır." sözlerinden ve KÖ(27)'nin "Çok faydalı, ... Endüstriyel tasarım beyin gelişimi ve yaratıcılık aynı zamanda öze dönmek için çok önemlidir." şeklindeki sözlerinden genellikle birlikte düşünüldüğü anlaşılmaktadır.

Öğretmenlerin endüstriyel tasarım atölyesinin katkıları konusunda dile getirdikleri bir başka yararlı yön, bu eğitimin öğrencilerin motor becerilerine, özellikle de el becerilerinin gelişimine sağladığı katkıdır. KÖ(8) bu gelişimi “.... bizi derste aktif bir hale getirdiğini düşünüyorum. Tekdüze bir öğretmen olmadığımızı çocuklara atık malzemelerle ya da kolayca bulunabilecek tüm malzemelerle üç boyutlu, iki boyutlu, işlevsel işleri çok basit bir şekilde hayata geçiriyoruz. Öğrencilerin el becerileri malzeme bilgisi ile çok daha fazla artıyor." sözleriyle ifade etmiştir.

Atölyenin katkıları konusunda değinilmesi gereken diğer bir nokta çalışmaların öğrencilere farklı bakış açılarıyla düşünme ve çalışmalar üretebilme becerisi kazandırdığı yönündeki görüşlerdir. KÖ(23) bu yöndeki düşüncesini "Ben endüstriyel tasarım dersinin öğrencileri tek tip olmak zorunda kalmaktan kurtardığını düşünüyorum. Öğrencilerin vitray, mozaik, üç boyutlu tasarım gibi birçok algısına hizmet eden farklı bir bakış açısını getirdiğini düşünüyorum." sözleriyle ortaya koyarken KÖ(4) ise "Çok faydalı çocuklar her zaman değişik çalışmalar yapmaktan hoşlanır ve endüstriyel tasarım bu anlamda çok önemli ve çocukların sevebileceği bir sanat dalı." şeklindeki sözleriyle dile getirmiştir.

Yukarıda betimlenen katkıların dışında öğretmenler, endüstriyel sanat atölyesinin üç boyutlu çalışmalara imkan tanıması, öğrencinin kendisini tanımasına yardımcı olması, grup çalışmalarına imkan vermesi, öğrencileri araştırıp öğrenmeye teşvik etmesi, çok yönlü olmayı sağlaması, psikolojik gelişime destek vermesi, sahne dekoru hazırlama gibi farklı etkinliklerde yardımcı olması ve özgüven sağlaması gibi katkılarından söz etmişlerdir. Öğretmenlerin bu konulardaki ifadelerinden bazı örnekler aşağıda sunulmuştur:

KÖ(10): “özellikle ilk-orta öğretimde öğrencilere yaptırılan 3 boyutlu çalışmalarda endüstriyel tasarım oldukça yararlı bir ortam sunuyor."

KÖ(18): "Ders dışında psikolojik olarak da öğrenciye nasıl yaklaşılması gerektiğini yumuşak ve sert malzemelerle öğrencinin dokunarak hissederek yaşayarak kendini anlatmasını ifade etmesini öncelikle severek yaklaşmasını sağladığını düşünüyorum."

KÖ(42): "Tabii ki, hem de çok önemli, el becerisi, malzemeyi tanıma, proje tasarımları derken öğrencinin bakış açısı gelişiyor, kendini tanıyor, başarı ve yaratıcılık duygusuyla birlikte özgüveni yükseliyor." 


\section{RiöLP içeriğinin ilk ve ortaöğretim kademelerine uygunluğu}

RiÖLP içeriği konusunda ortaya çıkan bir başka kategori RiÖLP içeriğinin ilk ve ortaöğretim programlarına uygunluğu konusundadır. Öğretmenlerin lisans programlarının ilk ve ortaöğretim programları ile paralellik göstermesine ilişkin görüşleri Tablo 7'te sunulmuştur.

\section{Tablo 7.}

Öğretmenlerin RiöLP iç̧eriğinin ilk ve Ortaöğretim Kademeleri Programıyla Paralellik Gösterme Durumuna iliş̧kin Görüşleri.

\begin{tabular}{|c|c|c|c|c|c|c|c|c|c|}
\hline & \multicolumn{9}{|c|}{ Mezun Olunan Anasanat Dalı } \\
\hline & 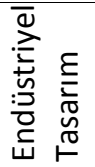 & $\begin{array}{l}\frac{\varepsilon}{\sqrt{y}} \\
\propto\end{array}$ & 美 & 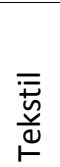 & $\begin{array}{l}4 \\
\frac{4}{50} \\
0 \\
0 \\
0 \\
+0\end{array}$ & $\begin{array}{l}\overline{\bar{d}} \\
\frac{\bar{d}}{I}\end{array}$ & 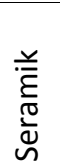 & 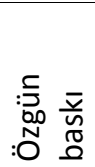 & $\frac{\frac{\varepsilon}{\pi}}{\frac{0}{0}}$ \\
\hline Paralel & 6 & 1 & 3 & 5 & - & - & - & - & 15 \\
\hline Kısmen paralel & 3 & 4 & 1 & 1 & - & - & - & - & 9 \\
\hline Paralel değil & - & 3 & 3 & 4 & 3 & 1 & 1 & - & 15 \\
\hline Toplam & 9 & 8 & 7 & 10 & 3 & 1 & 1 & - & 39 \\
\hline
\end{tabular}

Tablo 7, öğretmenlerin mezun oldukları anasanat dalına göre ilk ve ortaöğretim programları ile RiöLP arasındaki paralelliğe ilişkin düşüncelerini göstermektedir. Buna göre bu kademelerdeki programların birbirleriyle paralel olduğuna ve olmadığına ilişkin toplam görüşler benzer bir oranda olsa da endüstriyel tasarım atölyesi mezunlarının, RiöLP içeriği ile öğretim yaptıkları kademelerin programlarının içeriğinin birbirine paralel olduğu yönünde daha olumlu görüşe sahip oldukları görülmektedir. Nitekim hiçbir endüstriyel tasarım anasanat dalı mezunu öğretmen bu kademlerdeki programlar arasında paralellik olmadığı yönünde görüş belirtmemiş, 3 tanesi kısmen paralel olmadığını belirtmiştir.

\section{RiöLP'de Gerçekleştirilen Değişiklikler}

Öğretmenler, ankete verdikleri yanıtlarda zaman zaman RiÖLP'nin yapısında gerçekleşen değişikliklere atıfta bulunmuşlardır. Bu konudaki görüşlerin analizinden branşlaşmanın olumsuz etkisi ve iş-tasarım atölyesinin endüstriyel tasarım atölyesi olarak düzenlenmesinin olumlu katkısı şeklinde iki kategoriye ulaşılmıştır.

\section{Branşlaşmanın olumsuz etkisi}

Öğretmenler, RiÖLP'de gerçekleşen temel değişikliklerden birisi olarak ikinci sınıfta branşlaşmanın getirdiği olumsuz sonuçlara değinmişlerdir. Bu konuda ulaşılan kodlar Tablo 8'de sunulmuştur.

Tablo 8.

Branşlaşmanın Olumsuz Etkisi Kategorisine Ait Kodlar.

\begin{tabular}{lc}
\hline Kodlar & $\mathbf{f}$ \\
\hline Tek alanda uzmanlaşma sağlaması & 7 \\
Öğretmenlikten uzaklaşmaya yol açması & 13 \\
\hline
\end{tabular}

Tablo 8'de görüldüğü gibi öğretmenler, öğretmen adaylarının lisans eğitimleri sırasında atölye çeşitliliğini alamıyor olmaları ve ikinci sınıfta branşlaşmalarının olumsuz sonuçlara yol açtığını ifade etmişlerdir. Öğretmenler, RiöLP'nin yeniden yapılandırılmasının tek alanda uzmanlaşma sağladığını düşünmektedirler. Bu düşünceyi dile getiren bazı öğretmenlerin görüşleri aşağıdaki alıntılardan izlenebilir:

EÖ(37): "Tek Alanlı eğitim programını yeterli bulmuyorum. Eğitimcinin kapasitesini kısıtlamakta ve yönlendirdiği, eğittiği öğrencileri de kısıtlamaktadır. ... Tek alan sanat dalı mezunu öğretmen adaylarının bazı temel bilgi ve becerilerden yoksun olduğu kesindir. Bunu yaşanılmış örneklerden 
biriyle izah etmek isterim. ... Türkiye'deki bütün güzel sanatlar liseleri öğretmenlerinin katıldığı bir toplantıda X Güzel Sanatlar Lisesinden bir eğitimci arkadaşın Bakanlık görevlilerine haklı seslenişine ortak oldum. Konu, modelaj dersi. Öğretmenimiz 'nasıl uygulayacağımı bilmiyorum' diyor. O kadar çaresiz ki ve gözlerinden okunuyor bırakın uygulamayı temel bilgisi bile yok. Tartışma yarım saat sürdü ve inan kendi adıma sıkıldım ve tartışmaya dahil oldum. 'Özür dilerim hocam siz ne mezunusun' diye sorduğumda olayın boyutunu anladım. Çünkü hiç heykel atölyesine girmemiş. Evet nasıl başarılı olacak bu eğitimci."

KÖ(13): "Şu anki resim -iş öğretmenliği tek branşlı eğitim üzerine temellendirilmiş olması sıkıntılı bir durumdur. Eksik eğitim söz konusudur."

Bazı öğretmenler, farklı birçok atölyeden ders alabilme imkanı varken tek alanda uzmanlaşmanın öğretmenlikten uzaklaşılmasına yol açacağını, bunun da eğitim fakültelerinin dışındaki diğer sanat eğitimi kurumlarının amacı olduğunu vurgulamaktadırlar. Örneğin KÖ(42) “... Aksi takdirde tek bir alan seçip sanatçı olmanın yolunu açan başka üniversiteler tercih edilmelidir" şeklindeki sözleriyle, bu düşünceyi dillendirmiştir. KÖ(16) da "biz tekstilci, grafiker vs. olarak meslek hayatımızı devam ettirmiyoruz. Biz Öğretmen olarak mezun oluyoruz. Diplomamız bu meslekte işimize yarıyor o halde neden Görsel Sanatların kapsamına giren her türlü ana sanat dalının (Seramik, heykel, baskı atölyesi, Entas vs) hakkında fikir sahibi olmuyoruz. Keşke bütün Ana sanat dalı derslerinden yararlanarak çok yönlü bilgiyle mezun olabilseydik diye düşünüyorum." şeklindeki ifadeleriyle bu duruma dikkat çekmiştir.

\section{Iş tasarım atölyesinin endüstriyel tasarım atölyesi olarak düzenlenmesinin olumlu katkısı}

Öğretmenlerin RiÖLP'de gerçekleştirilen değişiklikler sürecinde iş tasarım atölyesinin endüstriyel tasarım atölyesi olarak düzenlenmesi konusunda ise olumlu düşündükleri belirlenmiştir. Bu konuda ulaşılan kodlar Tablo 9'de sunulmuştur.

\section{Tablo 9.}

Iş Tasarım Atölyesinin Endüstriyel Tasarım Atölyesi Olarak Düzenlenmesinin Olumlu Katkısı Kategorisine Ait Kodlar.

\begin{tabular}{lr}
\hline Kodlar & $\mathbf{f}$ \\
\hline Konu, malzeme ve tekniğin değişip zenginleşmesini sağlaması & 11 \\
Teknoloji Tasarım dersine uygunluğu & 8 \\
Okul içi faaliyetlere katkı sağlaması & 2 \\
\hline
\end{tabular}

Öğretmenler, RiöLP'de meydana gelen önemli ve olumlu değişikliklerden birisi olarak İş ve Tasarım atölyesinin endüstriyel tasarım atölyesi olarak düzenlenmesini belirtmişlerdir. Bu şekilde düşünen öğretmenlere göre İş ve Tasarım dalı endüstriyel tasarım atölyesi olarak değiştirilmesi, malzemeye bakışın değişip zenginleşmesinde önemli bir rol üstlenmiştir. İş tasarımı atölyesinden ders almış olan ve sonrasında endüstriyel tasarım atölyesinin sergisinde bulunan öğretmenler bu iki ders arasındaki farklılaşmayı olumlu gördüklerini ifade etmişlerdir. Örneğin KÖ (15) "Atölyenin o dönemde küçük ve yeterli malzeme donanımına sahip olmadığını hatırlıyorum. Gelecekte farkında olmadan işimize öğretmenliğimize faydası bu denli çok olacak bir dersi kesinlikle yeterli-gerekli buluyorum. Belki de öğretmen adaylarına bunun önemi öğrencilik dönemin de anlatılsa çok daha faydalı olur." sözleriyle, KÖ (41) ise "keşke daha çok ve farklı konular olsa idi. Bu sene gittiğimde daha farklı çalışmalar gördüm, taş veya camla, bunları ben çalışma hayatımda öğrenip kullanmıştım, okulda öğrenilerek uygulanıyor olması daha olumlu tabi." şeklindeki sözleriyle malzemeye bakış açısının değişmesi ve zenginleşmesine vurgu yapmışlardır. Aynı konuya vurgu yapan $\mathrm{KÖ(2)}$ ise bu konudaki düşüncelerini "Endüstriyel Tasarım atölyesini bu yıl gezdiğimde çok farklı ve güzel tekniklerin uygulandığını görmek beni heyecanlandırdı." sözleriyle ifade etmiştir. Buradan da anlaşıldığı üzere 1998 öncesi eğitimin, yani İş ve Tasarım Anasanat Dalının daha çok iş eğitimi dersine karşılık geldiğinden ve daha farklı içerikleri kapsadığından, sanat yaratıcılığından daha uzak olduğundan, oysa günümüzdeki endüstriyel tasarım atölyesinin öğretmen 
adayları için daha geniş malzeme ve bakış açısı sunduğundan ve daha yaratıcı ve iyi bir eğitim aldıklarından söz edilebilir.

Bazı öğretmenler, meydana gelen değişikliğin Teknoloji Tasarım dersine olan faydalarını ve ders dışı öğretmenlik faaliyetlerine yaptığı katkıları dile getirmişlerdir. Örneğin KÖ(42) bu konudaki görüşlerini “...benim çok işime yaradı doğrusu... Özel okulda özellikle de sahne dekoru hazırlıyordum sürekli. Ya da milli bayramlarda orijinal malzemeler düşünüp, öğrencilerle birlikte uygulama yapıp sunmak çok keyif verici olmuştur. Teknoloji Tasarım derslerinde proje konularında özellikle de bu dersleri almakla işimin ne kadar kolaylaşıp keyifli hale geldiğini hep düşünmüşümdür." şeklinde dile getirmişken KÖ(09) "Endüstriyel Tasarım dersini almamış bir öğretmen, her iki sanat dersinde de yetersiz kalıyor" sözleriyle bu katkıya değinmiştir.

\section{Öğretmenlerin RiöLP'ye İlişkin Önerileri}

Öğretmenler, ankette yer alan çeşitli sorular altında RiÖLP’ye ve ETE'nin ilköğretim ve ortaöğretim kurumlarında daha etkili gerçekleştirilmesine ilişkin öneriler dile getirmişlerdir. Bu ifadelerin analizi sonucunda programın geliştirilmesi, akademisyenler, eğitimin amacı, eğitim yöntemi, eğitim ortamları ve kurumlar arası işbirliğine ilişkin öneriler olmak üzere altı kategoriye ulaşılmıştır.

\section{Programın geliştirilmesi ile ilgili öneriler}

Öğretmenlerin programın geliştirilmesi ile ilgili önerilerine ilişkin ulaşılan kodlar Tablo 10’da sunulmuştur.

Tablo 10.

Programın Geliştirilmesi Ile IIgili Öneriler Kategorisine Ait Kodlar.

\begin{tabular}{lc}
\hline Kodlar & $\mathbf{f}$ \\
\hline Her anasanat dalıyla/atölyeyle ilgili ders alma imkanı sunulması & 22 \\
Yan sanat sınırlılığın kaldırılması & 11 \\
1998 öncesi programın model olması & 6 \\
Atölye ders saatlerinin arttırılması & 12 \\
Esnek çalışma sürelerinin olması & 1 \\
Staj süresinin uzatılması & 3 \\
Formasyon derslerinin süresinin azaltılması & 2 \\
Resim atölyesinin zorunlu ve temel atölye olması & 1 \\
Endüstriyel tasarım atölyesine daha fazla önem verilmesi & 6 \\
Endüstriyel tasarım derslerinin zorunlu olması & 3 \\
Sahne ve dekor içerikli ders eklenmesi & 1 \\
Sanat eğitiminin gerekliliği konusundaki derslerin yer alması & 2 \\
Çocuk psikolojisine ilişkin derslerin yer alması & 1 \\
Ilk ve ortaokullarda yapılabilecek etkinlikleri içeren bir dersin yer alması & 1 \\
Hayal gücünü destekleyici konuların tercih edilmesi & 6 \\
\hline
\end{tabular}

Tablo 10'da görüldüğü gibi öğretmenlerin en sık vurguladıkları öneriler programın yapısı ve içeriğinin geliştirilmesi konusundadır. Bu kapsamda en sık dile getirilen öneri ise öğretmen adaylarına her anasanat dalından ders alma imkanının sağlanması konusunda olmuştur.

Bu konuyla ilgili önerilerden bir diğeri 1998 öncesi programa dönülmesi ve yan sanat sınırlılığının kaldırılması şeklinde dile getirilmiştir. Bu konulara değinen bazı öğretmenlerin görüşleri aşağıdaki alıntılardan izlenebilir:

KÖ(4): "Anasanat dışındaki yan sanatlar eklenmeli ve sadece iki yan sanatla sınırlı kalınmaması (gerekir)." 
EÖ(7): “..amaçta öğretmen yetiştirilme konusuna uygun bir hedef olduğuna göre tüm öğrenciler tüm bölümlerle ilgili dersler de almalı ki öğretmenlik amacında olan öğrenciler dolu dolu olan bir birikimle öğrencilerinin karşısına çıkabilsinler."

KÖ(17): "Mezun olana kadar bütün dallar görülmeli. Birçok teknik eksik kaldı."

KÖ(35): "Üniversitelerde mutlaka her öğrencinin her atölyeden faydalanmasını sağlayan bir program olmalı."

KÖ(27): "98 öncesi gibi olmalıdır hatta daha da geliştirilmelidir".

KÖ(39): "Her branştan, belirli saatlerde atölye dersleri sağlanılırsa, öğretmen adayı daha yetkinyaratıcı ve disiplinler arası eğitim aldığından öğretmen olduğunda üreteceği planlarda da daha verimli olacaktır. Ben 2006 mezunuyum, 2. sınıftan itibaren özgün baskı ve resim atölyelerine katıldım. Her dönem dönüşümlü olarak diğer branşlarda da eğitim almak isterdim. Ancak mümkün değildi."

Öğretmenlerin RiöLP konusundaki getirdikleri önerilerden bir diğeri atölye ders sürelerinin arttırılması konusunda olmuştur. Bir öğretmen ise ayrıca esnek çalışma sürelerinin olması gerektiğini belirtmiştir. Staj sürelerinin uzatılması da ders süreleri ile ilgili gelen öneriler arasındadır. Buna karşın iki öğretmenin ise programlarda yer alan formasyon derslerinin azaltılması yönünde öneride bulunmaktadır. Ders süreleri ile ilgili görüş bildiren öğretmenlerin ifadelerinden bazı alıntılar aşağıda sunulmuştur:

KÖ(8): "Ders saati ne kadar fazla olursa yaratıcılık ve ortaya çıkan ürün kalitesinin bir o kadar artacağını düşünüyorum."

KÖ(13): "Atölye ders saatleri arttırılmalı, ana sanat dalı dışında birbirleriyle bağlantılı el becerisine ve akademik çalışmaya yönelik derslerin atölye ortamında doyurucu saatlerle öğrencilere verilmesi gerekir."

KÖ(32): "Üniversite öğretmenlerinin de görüşleri alınarak faydalı olunabileceğine inanılan temel derslerin verilmesi konusunda programlar iyileştirmeli bazı ders saatleri arttırılmalı."

KÖ(22): “... formasyona bağlı ders anlatım sürecinin saatleri indirilmelidir... Aynı bilgiler daha az ders saati içerisinde de hızlandırılmış olarak verilebilir. Bu durum özellikle 4. Sınıf verimliliğini azaltmaktadır."

KÖ(34): "Atölye ders saatlerinin arttırılması, daha esnek çalışma sürelerinin olması, atölyelere saatli giriş ve çıkış olmaması, nitelikli akademisyenler ve üniversite giriş sınavlarında da bazı değişikliklerle verilecek eğitim daha nitelikli bir hal alabilir."

Bazı öğretmenler lisans programının geliştirilmesi konusunda belirli derslere daha çok önem verilmesi, endüstriyel tasarım ve resim atölyelerinin zorunlu olması ya da okul uygulamalarına yardımcı olacak derslerin eklenmesi konusunda önerilerde bulunmuşlardır. Farklı öğretmenler programa örneğin sahne ve dekor, çocuk psikolojisi, ilk ve ortaokullarda yapılabilecek etkinlikler, sanat eğitiminin gerekliliği konulu derslerin eklenmesi konusunda öneride bulunmuşlardır. Bir başka öğretmen ise hayal gücünü destekleyici konuların tercih edilmesi gerektiğini dile getirmiştir. Bu çerçevede görüş belirten öğretmenlerden bazıları bu düşüncelerini aşağıdaki şekilde dile getirmişlerdir:

KÖ(8): "Endüstriyel Tasarım atölyesi mezunu olarak atölyeye daha fazla önem verilmesi gerektiğini düşünüyorum. Malzeme ve yaptırılan işler bakımından nitelikli öğretmenlerin bu bölüm mezunlarından çıktığını düşünüyorum. ... Tüm öğretmenlerin bu bilgiyi alması gerektiğini düşünüyorum."

KÖ(9): “...proje hedefli bir eğitim uygulanıyor. Bu yüzden Resim öğretmenliğinde Endüstriyel Tasarım dalının öneminin kavranması gerektiğini düşünüyorum. Ve kesinlikle bir resim öğretmeni bu atölyeden çıktığı zaman mesleki yeterliliğiyle daha başarılı olacaktır."

KÖ(29): "Ana sanat dalının yanında endüstriyel tasarım dersinin ek olarak tüm öğrencilere zorunlu ders olarak okutulmasının çok faydalı olacağı kanaatindeyim."

KÖ(28): "Özel Okulda çalışan bir Resim Öğretmeni olarak okulda sahne ve dekor çalışmalarını yoğun olarak çalışıyoruz. Bu konuda belki Sahne ve Dekor kapsamında dersler eklenebilir." 
KÖ(25): "Daha fazla okul deneyimine ve uygulamalarına öncelik verilirse öğretmen adayları zorluk çekmeyebilir."

KÖ(24): "Çocuk psikolojisini daha iyi kavrayabileceğimiz uygulamalı çocuk psikolojisi dersleri konulabilir diye düşünüyorum."

\section{Akademisyenlerle ilgili öneriler}

Öğretmenlerin RiÖLP'lerde eğitim veren akademisyenlerle ilgili önerileri konusundaki ifadelerinin analizinden ulaşılan kodlar Tablo $11^{\prime}$ da sunulmuştur.

Tablo 11.

Akademisyenlerle Ilgili Öneriler Kategorisine Ait Kodlar.

\begin{tabular}{ll}
\hline Kodlar & $\mathbf{f}$ \\
\hline Akademisyenlerin donanımlı olması & 2 \\
Akademik kadroların geliştirilmesi & 2 \\
Eğitimcilerin öğrencileri motive etmesi & 3 \\
Sanat etkinliklerine önem verilmesi & 4 \\
Yeni projeler oluşturulması & 1 \\
Akademisyenlerin öğrenci ve mezunlarıyla iletişim halinde kalmaları & 1 \\
Akademisyenlerin okul ortamları ve programlarını takip etmeleri & 1 \\
\hline
\end{tabular}

Yukarıdaki kodlar incelendiğinde öğretmenlerin, akademisyenlerin donanımlı olmalarının sağlanması, üniversitelerdeki kadroların sayı olarak artırılması, akademisyenlerin öğrencilerini geliştirecek yönde projeler üretmeleri ve öğrencileri ve mezunları ile sürekli iletişimde olmaları gibi öneriler dile getirdikleri görülmektedir. Bununla birlikte değinilen önerilerden bir diğeri de akademisyenlerin öğretmen yetiştirdikleri kurumların ortamlarını ve programlarını takip etmeleridir. Öğretmenlerin akademisyenlerle ilgili önerileri aşağıdaki alıntılarda görülmektedir:

KÖ(21): "Atölyelerin değiştirilip öğretime daha uygun hale getirilmesi ve günceli yakalamak açısından daha aktif ve bilgi sürekli yenilenir bakış açısında olan hocaların öğretime dahil olması gerektiğini düşünüyorum."

KÖ(23): "Bu dersi verebilecek öğretim üyelerinin tam kadro ve donanımlı olması 31. Madde ile görevlendirilen öğretim görevlilerinin yeterli donanımda olduğu kanaatinde değilim. Ders ücretlerinin yetersiz olması başarısızlığın ve isteksizliğin temel nedenlerindendir."

KÖ(17): "Üniversite öğretim görevlileri ilk ve orta öğretim programlarını incelemeli söz ve yetkileri olmalı mezun ettikleri sanat eğitimcileri ile bağlarını koparmamalı her yıl değişik ilçelerdeki orta ve ilköğretim okulları gezilmeli..."

\section{Eğitimin amacına ilişkin öneriler}

Öğretmenlerin RiÖLP’nin amacına ilişkin bazı önerilerde bulundukları görülmüştür. Bu konudaki analiz sonucunda ulaşılan kodlar Tablo 12'de sunulmuştur.

Tablo 12.

Eğitimin Amacına iliş̧kin Öneriler Kategorisine Ait Kodlar.

\begin{tabular}{ll}
\hline Kodlar & $\mathbf{f}$ \\
\hline Sanat bilinci oluşturmaya odaklanılması & 2 \\
Sanat öğretimine odaklanılması & 2 \\
Öğretmen yetiştirme amacına odaklanılması & 9 \\
Sanat öğretmenliğinin önemine vurgu yapılması & 3 \\
Sanatın toplum yaşamındaki önemini vurgulanması & 1 \\
Çok yönlü birey yetiştirmeye odaklanması & 6 \\
\hline
\end{tabular}


Tablo 12'deki kodlar incelendiğinde bu kategoride betimlenen düşüncelerin daha çok sanat eğitiminin vurgulanması amacını taşıdığı görülmektedir. Öğretmenlerin, eğitimin, sanat bilincinin oluşturulması, sanat eğitimciliğine odaklanılması, sanat öğretmenliğinin önemine vurgu yapılması, sanatın toplumda yaşamındaki öneminin vurgulanmasını amaçlaması konusunda görüş bildirdikleri belirlenmiştir. Bununla birlikte bu eğitimin çok yönlü birey ve öğretmen yetiştirme amacına odaklanması gerektiği de tespit edilen diğer görüşler arasındadır.

KÖ(20): "Daha çok öğretmen yetiştirme amaçlı bir eğitimin her zaman daha verimli olacağını düşünüyorum."

KÖ(39): “... disiplinler arası her branşın (dönemsel bile olabilir) atölye dersleri olan, Sanat eğitimciliği üzerine derslerin verildiği, Pedagojik eğitimde belli derslerin birleştirilerek sanat eğitimciliği nasıl olur? Üzerine planlanırsa öğretmen adayı için daha verimli olacaktır."

EÖ(15): "Daha bilinçli, kendini yenileyen, gelişimlere açık, sanatı sürekli takip eden, sadece yaratan değil yaşayan da olmalarını hep hissettirmek bence en önemli unsur. Onlar birer öğretmen adayı ama diğer öğretmenden farkları olduğunu asla unutmamalılar. Çünkü sanat öğretmeni olmak farklıdır. Üstümüze düşen bu önemli görevin farkında olarak onları yetiştirmek zorundayız."

EÖ(11): "Sanat yaşamının toplumsal hayatin vazgeçilmez bir unsuru olduğunu bütün öğrencilere tüm ciddiyetiyle hissettirmek ve bu bilinci yerleştirmek (gerekir)."

KÖ(41): "...çağdaş öğrenciyi sanat olgusunun içine çekebilecek nitelikte öğretmen yetiştirmeyi amaçlamalıdır."

\section{Eğitim yöntemine ilişkin öneriler}

Öğretmenlerin bazıları RiÖLP'de verilen eğitimin yöntemine dair önerilerde bulunmuşlardır. Bu konudaki ifadelerin analizinden ulaşılan kodlar Tablo 13'de sunulmuştur.

Tablo 13.

Eğitim Yöntemine Iliş̧in Öneriler Kategorisine Ait Kodlar.

\begin{tabular}{ll}
\hline Kodlar & $\mathbf{f}$ \\
\hline Pratik bilgiye önem verilmesi & 3 \\
Sanat eğitiminde araştırmaya yer verilmesi & 2 \\
Formasyon dersleri ile ana sanat dersleri arasındaki bağlantının güçlendirilmesi & 3 \\
Aktif öğrenme yöntemlerinin kullanılması & 5 \\
Sanatsal etkinliklerle iç içe olunması & 1 \\
\hline
\end{tabular}

Öğretmenler, RiöLP'de verilen eğitimin yöntemine ilişkin farklı önerilerde bulunmuşlardır. Örneğin K(5) "Teorik bilgiden ziyade pratik bilginin fazlalaştırılması." sözleriyle pratik bilginin önemine değinirken K(19) da "Sanat eğitimi kapsamında araştırmaya yönelik çalışmalara yer verilmeli... Uygulamalı saatler arttırımalı." sözleriyle eğitimlerin araştırmaya ve uygulamaya yönelik olmasına ilişkin öneriler getirmiştir. Bu konuda $\mathrm{K}(1)$ ise formasyon dersleri ile ana sanat dersleri arasındaki bağlantının güçlendirilmesi gerektiğini "Formasyon dersleriyle ana sanat dersleri paralel ilerlemeli, fazla bağımsızlar." sözleriyle dile getirmiştir. Lisans programında verilen eğitimin yöntemine ilişkin olarak öğretmenler ayrıca öğretim üyelerinin rehberliğinde aktif öğrenme yöntemlerinin kullanılması ve sanatsal etkinliklerle iç içe olunarak bu eğitimin gerçekleştirilmesi gerektiğini belirtmişlerdir. Bu konuda görüş bildiren öğretmenlerin ifadeleri aşağıda görülmektedir:

KÖ(10): "Öğrencilerin aktif olarak derse katılımını sağlayacak, ilgilerini çekecek ve yaratıcılıklarının gelişiminin sağlanması için öğretmen adaylarının, uzmanların bu konuda workshop ve beyin fırtınası gibi çalışmalar yaparak bu konunun geliştirilmesi gerektiğini düşünüyorum."

KÖ(6): "Güncel sanatsal olaylardan tutun da, malzeme kullanımlarına kadar sınırların zorlanması gerektiğini düşünüyorum. Aktif sanatsal etkinliklerle iç içe olunması gerektiğini ve eğitimcilerin bu anlamda öğrencileri desteklemesi gerektiğini, eğitimcilerin öğrencileri heyecanlandıracak yeni projeler oluşturmaları gerektiğini düşünüyorum." 


\section{Eğitim ortamları ile ilgili öneriler}

Öğretmenlerin RiöLP'nin ETE için daha işlevsel olarak hizmet vermesi yönündeki önerilerinden bazılarının eğitim ortamları, özellikle atölye ortamları ile ilgili olduğu görülmüştür. Bu konuda ulaşılan kodlar Tablo $14^{\prime}$ te sunulmuştur.

\section{Tablo 14.}

Eğitim Ortamına iliş̧kin Öneriler Kategorisine Ait Kodlar.

\begin{tabular}{ll}
\hline Kodlar & $\mathbf{f}$ \\
\hline Atölyelerdeki konforun geliştirilmesi & 2 \\
Atölyelere elektronik aletlerin eklenmesi/teknolojiye açık olunması & 5 \\
Farklı materyallerin geliştirilmesi & 2 \\
\hline
\end{tabular}

Tablo 14 incelendiğinde öğretmenlerin özellikle atölye ortam ve imkanlarının geliştirilmesi konusunda önerilerde bulundukları görülmektedir. Atölyelerdeki konforun geliştirilmesi, yeni aletlerin eklenmesi, farklı materyallerin geliştirilmesi bu konuda dile getirilen önerilerdir. Öğretmenlerin bu konudaki ifadelerinden bazı alıntılar aşağıda sunulmuştur:

KÖ(3): "Materyaller geliştirilebilir, daha fazla tehcizat ile işler kolaylaştırılabilir. Elektronik aletler muhakkak eklenmeli ve yeterli sayıda olmalı."

KÖ(16): "Öncelikli önerim, eğitimin daha etkin verilebilmesi için atölyelerin daha donanımlı, konforlu olması gerektiğini düşünüyorum."

\section{Kurumlar arası işbirliğine ilişkin öneriler}

Öğretmenlerin RiöLP’nin ETE’yi desteklemesine ilişkin önerilerden sonuncusu kurumlar arası işbirliğine ilişkin öneriler başlığı altında ele alınmıştır. Sadece bir koda ulaşılabilen kategori altında öğretmenlerin lisans programları ile MEB ilk ve ortaöğretim kademelerinin uygulamaları arasındaki tutarsızlıkların giderilmesi için ve MEB'in alanla ilgili politikalarında üniversitelerin daha çok söz sahibi olması gerektiğine ilişkin öneri dile getirilmiştir. "MEB-üniversite işbirliğinin geliştirilmesi” şeklinde ifade edilen bu kodu içeren alıntılar aşağıda sunulmuştur:

KÖ(2): "Milli Eğitim Bakanlığı ortak dersler birimi ile işbirliği içinde olunması, dersimizin süresinin yetersizliğinin ortaya konularak haftalık ders saatinin birden ikiye çıkartılarak ve blok olarak uygulaması maddesinin yerleştirilmesi konusunda üniversite ile işbirliğinin sağlanmasının yaralı olacağını düşünüyorum."

KÖ(17): "MEB ile işbirliği... 1 saat işlenen sanat eğitimi zor koşullarda maalesef. birçok okulda atölye yok. Ortaöğretim programı ilköğretimin tekrarı gibi."

\section{Sonuç, Tartışma ve Öneriler}

Resim-Iş Öğretmenliği programlarının öğretmen adaylarına Görsel Sanatlar/Resim-Iş dersi kapsamında sürdürülen ETE için gerekli yeterlikleri kazandırma işlevlerini ne kadar ve ne şekilde gerçekleştirdiğinin araştırıldığı bu çalışmada, bu yeterliklerin kazandırılmasının söz konusu programın yapısı kadar uygulanma biçimine de bağlı olduğu ortaya çıkmıştır. Öğretmenler, belirtilen yeterliklerin kazandırılması konusunda atölye çeşitliğinin yararlarına, atölye sürelerinin önemine ve atölye içeriklerine dair görüşler dile getirmişlerdir. Bu sonuçlara göre öğretmenlerin anlatımlarından, atölye çeşitliliğinin öğretmenlerin mesleki donanımları, yetkinleşmeleri ve niteliklerinin geliştirilmesi açısından temel oluşturduğu, uygulamaların gelişip zenginleşmesine, yaratıcılığın gelişmesine ve malzeme bilgilerinin artmasına imkan tanıdığı anlaşılmaktadır. Bu düşünceler, tüm dalların dönüşümlü olarak alındığı eski RiöLP mezunlarının yeni gelen öğretmenlere göre aldıkları atölye eğitimi açısından daha donanımlı olduklarını belirtmeleri ve sonraki program mezunlarının ise tüm dallardan özellikle de malzeme ve proje çeşitlilikleri ve çok yönlü eğitimin verilmesi açısından farklı atölyelerden ders almış olma istekleriyle desteklenmektedir. İkinci sene her daldan ders alınmış olması hem donanım hem de öğretmen olacak kişinin kendini keşfetmesi açısından olumlu iken ilköğretim birinci ve ikinci kademede çok yönlü verilen 
sanat eğitiminde çocuğun yeteneklerini tespit etmek ve gelişmesi için de önemlidir. Özellikle özel okul ve bazı devlet okullarında da oluşturulabilen kulüp çalışmalarında farklı kulüplerin ön plana çıkmasında da etken, üniversitedeki atölye çeşitliliği zenginliğinden kaynaklanmaktadır. Okullarda yaratıcılı̆ı̆n geliştirilmesinde en önemli çalışma alanlarından biri olarak görülen sanat ve iş eğitimi, gerek çalışma biçimi, gerek bu çalışmalarda kullanılan araç, gereç bolluğu ve gerekse öğrenciye sağladığı çalışma serbestliği sayesinde kuşkusuz öteki dersler arasında çok önemli bir yere sahiptir (Sarı, 2000) ve bu görüş öğretmenler tarafından da paylaşılmaktadır. Araştırmada çok yönlü eğitimin yaratıcılık üzerindeki olumlu etkisi şeklinde ulaşılan bu sonuca Uysal (2005) tarafından da değinilmektedir.

Araştırmanın temel sonuçlarından bir diğeri, atölye sürelerinin bu sürece katkısına ilişkindir. Öğretmenlerin \% 72'sinin atölye sürelerini yetersiz olarak nitelemeleri gerekli yeterliklerin kazandırılması açısından önemli bir soruna işaret etmektedir. Öğretmenler, atölye sürelerinin yetersizliğin eğitimin hızlandırılmış bir şekilde sürdürülmesi ve verimin düşmesi gibi sonuçlar doğurduğuna değinmişler, gerekli becerilerin kazanılması için şart olan pratik yapma konusunda sıkıntılar olduğunu belirtmişlerdir. Bu çalışmada ulaşılan bu sonuç, Özsoy ve Şahan (2009), Buyurgan (2007) ve Kavuran (2003)'ın çalışmalarında ulaşılan sonuçları desteklemektedir. Araştırmaların genel sonucu ders saatlerinin arttırılması yönündedir.

Bu çalışmanın ortaya koyduğu en önemli sonuçlardan birisi de Endüstriyel Tasarım Anasanat Dalının ETE yeterliklerinin kazandırılması konusunda önemli bir role sahip olduğu görüşüdür. Araştırmaya katılan öğretmenler, RiÖLP içeriğindeki atölyelerden endüstriyel tasarım atölyesini bu yeterliklerin kazandırılması açısından en işlevsel atölye olarak sıralamış ve atölyenin katkılarına dair birçok neden belirtmişlerdir. Ayrıca RiöLP ile ilk ve ortaöğretim programları arasındaki paralellik açısından değerlendirmelerinde ise endüstriyel tasarım atölyesi mezunlarının bu programların birbirleriyle daha çok paralellik gösterdiğine dair görüşleri de bu durumu desteklemektedir. Endüstriyel tasarım atölyesi mezunlarının kendi uygulamaları hakkındaki olumlu yargıları ile ortaya çıkan bu sonuç, bu atölyeden mezun olmayan öğretmenlerin endüstriyel tasarım mezunu öğretmenlerin faaliyetlerine ilişkin olumlu yöndeki gözlemleri ile de desteklenmiştir. Öğretmenler, "Resim-iş̧" bütünlüğündeki genel çerçevede "Endüstriyel Tasarım" Atölyesinin varlığının yadsınamayacağını, öğrencilerin üç boyutlu çalışmalardan etkilendikleri için öğrenmeye daha meraklı ve yaratıcı olduklarını ve bunun da ETE yeterliliğine kavuşmuş öğretmenler tarafından kolaylıkla sağlanabileceğini savunmuşlardır. Endüstriyel tasarım yeterliliğinin kazanılması, daha zevkli daha ilginç ve daha renkli projeler üretilebilme adına hem öğrenci hem de öğretmen için daha keyifli bir öğrenim hayatı sağlayabilme açısından önemlidir. Aynı şekilde geniş bir hayal gücüne ve bulunduğu durumu olumlu bir hale getirebilmek için gerekli pratik malzeme bilgisine sahip olmak bir öğretmen için çok önemlidir. Araştırma sonuçları bu yeterliğin kazandırılmasında Resimİ̧ Öğretmenliği Anabilim Dalı endüstriyel tasarım atölyesinin önemli bir potansiyele sahip olduğuna işaret etmektedir. Öğretmenlerin, endüstriyel tasarım atölyesi ile ilgili olarak dile getirdikleri temel kazanımlardan bir diğeri ise bu atölyelerin yaratıcılık üzerinde olumlu bir etkiye sahip olduğu şeklinde ifade edilebilir. Günümüzde endüstriyel tasarım atölyesine geniş bir perspektiften bakılacak olursa; bu içeriğin yaratıcı konu ve tekniklere yer verilerek özellikle çocuğun zeka ve yetenek gelişimini desteklediği, bireyin gerek bireysel özelliklerinin gerekse yeteneklerinin farkına varmasını ve geliştirmesini sağladığı söylenebilir. Öğretmenlerin endüstriyel tasarım atölyesinin son derece yaratıcı bireylerin yetişmesine olanak sağladığı görüşünde hemfikir oldukları görülmektedir.

Öğretmenlerin RiÖLP'de yapılan düzenlemeler kapsamında gerçekleştirilen ikinci sınıfta branşlaşma değişikliğine karşı genel olarak olumsuz düşündükleri, iş ve tasarım dersinin endüstriyel tasarım atölyesi olarak değiştirilmesini ise olumlu karşıladıkları tespit edilmiştir. Branşlaşmaya ilişkin olumsuz görüşlerin bu şekilde gerçekleşen bir eğitimin tek alanda uzmanlaşma sağlaması ve sonuçta öğretmenlik mesleğinden uzaklaşılmasına yol açması üzerine odaklandığı görülmektedir. Öğretmenler, eğitim fakülteleri kapsamında yer alan bu eğitimin öğretmen yetiştirmeye odaklanması gerektiğini, dolayısıyla tek alanda uzmanlaşmak yerine tüm atölyelerden belirli bir oranda bilgi ve beceri kazanılması gerektiğini vurgulamışlardır. Öğretmenlerin RiöLP'de gerçekleştirilen değişikliklere ilişkin olumlu olarak 
değerlendirdikleri husus ise iş ve tasarım atölyesinin endüstriyel tasarım atölyesi olarak düzenlenmesidir. Öğretmenlerin yorumlarında da görüldüğü gibi resim öğretmenliğindeki iş ve tasarım atölyesi içerik olarak farklılaşırken, yerini öğretmenliğe ışık tutan içerikle yoğrulmuş olan endüstriyel tasarım atölyesine bırakmıştır. Endüstriyel tasarım atölyesi yaratıcılığı daha ön plana çıkaran, çok farklı malzeme bilgisini içeren, bireysel farklııklara önem veren, coşkulu, motive eden, alanında iyi yetişmiş, sanatı seven anlayan bireyleri yetiştirmeye yol gösteren bir atölyedir. Aynı zamanda öğretmenlerin edindikleri bilgi ve becerileri hayatlarına da yansıtabildikleri ve belki de en önemli kazanımlarından birisi olan eleştirel bakış açısını geliştiren bir atölye olmuştur. Çoğu öğretmenin değindiği gibi bu atölye, öğretmenlikte en fazla kullandıkları ve öğrencilerin de en çok zevk aldığı atölyelerden birisi konumundadır. Geleneksel yöntemler mutlaka farklı materyallerle desteklenmelidir (Polat, 2013). Illköğretim ve ortaöğretim kademesinde daha önce Resim-iş olarak yer bulan ders, ismi değiştirilerek Görsel Sanatlar olmuş ve kapsamı da genişlemiştir. Ders ismi daha kapsamlı hale gelirken resim/görsel sanatlar öğretmeni yetiştiren kurumlarda zorunlu seçmeli atölyeleri ile birlikte tek atölyeye indirilmesi dersin adı ile ters düşmekte çünkü donanım eksikliğini getirmekte olduğu da inceleme sonucunda ortaya çıkmıştır. Öğretmenlerin de hemfikir olduğu gibi anasanat atölyenin yanında tüm atölyelerin eğitiminin de alınmasının önemli olduğu yönündedir. Ayrıca 2. sınıfta tüm dalları gören öğretmen adayı kendini daha iyi tanımasıyla 3. sınıfta daha uygun atölyeyi seçme şansını da yakalamış olacaktır. Kiprik'in de dediği gibi başarı ve performansın iyi düzeyde olması için öğrencilerin yeteneklerinin doğru tespiti önemlidir (Kiprik ve Şirin, 2012). Yaşanılan sosyo-ekonomik çevrenin verdiği imkanlar içerisinde yaşayabilecek problemlerle alternatif çözümler üretebilme yetileri geliştirici, çok yönlü eğitim önemlidir. Tek alan sanat dalı mezunu öğretmen adaylarının bazı temel bilgi ve becerilerden yoksun olduğu kesindir. Öğretmenlerin bu işaret ettikleri temel sonuçlardan birisi de bu değişikliğin Teknoloji Tasarım derslerine olan katkısı üzerindedir. Disiplinler arası çalışmalarda da atölye çeşitlilikleri ve kazanımlar önemlidir. Yapılabilecek şeyler çoğaldıkça paylaşımlarla zengin bakış açıları da gelişecektir.

Öğretmenlerin, ETE yeterliklerinin kazandırılması konusunda RiöLP'e yönelik bazı öneriler sundukları belirlenmiştir. Genel olarak programın geliştirilmesi, akademisyenler, eğitimin amacı, eğitimin yöntemi, eğitim ortamları ve kurumlar arası işbirliği çerçevesinde geliştirilmiştir. Adı geçen yeterliklerin kazandırılması konusunda öğretmenlerin en sık değindikleri konulardan birisi programların geliştirilmesi üzerine temellendirilmiş̧tir. Bu konuda öğretmenlerin en sık dile getirdikleri hususlar her anasanat atölyesinden ders alınma imkanının sunulması, 1998 öncesi yapının model alınması, atölye ders saatlerinin arttırılması olarak belirmiştir. Bununla birlikte bazı öğretmenler endüstriyel tasarım atölyesinin, bir öğretmen ise resim atölyesinin zorunlu ders olmasını önermiştir. Bunun dışında öğretmenlerin farklı konularda dersler eklenmesine yönelik öneriler de mevcuttur. Bu konuda staj sürelerinin uzatılmasına ve formasyonla ilgili derslerin eklenmesine ilişkin öneriler de getirilmiştir. Programlarda uygulamaya daha çok yer verilmesi gerektiğine dair bulgu Ayaydın (2011)'ın çalışmasında da tespit edilmiştir. Öğretmenler akademisyenlerle ilgili olarak mesleki donanımlarının sağlanması, üniversite kadrolarının geliştirilmesi gerektiğini dile getirmişken eğitim ortamlarını özellikle malzeme açısından geliştirilmesi gerekliliğine dikkat çekmişlerdir. Gelişen teknolojiyle birlikte tüm atölyelerde olduğu gibi burada da içerik ve malzeme kullanımları açısından, sürekli kendini güncelleyebilmek adına, gerekli imkanlar sunulmalıdır. İz Bölükoğlu (2002) ve Zeren (2006)'in de belirttikleri gibi bilgi çağının gerekliliklerinin ve teknoloji imkanlarının sanat eğitimi ortamlarına yansıtılması, eğitimin bu imkan ve gereklilikler çerçevesinde düzenlenmesi gerekmektedir. RiÖLP'nin amaç ve kapsam olarak ilk ve ortaokulların programıyla paralellik gösterecek şekilde yeniden yapılandııılması, ders içeriğinin ve saatinin oturmaması ve bu kapsamda programın tekrar ele alınması ihtiyacı değerlendirilmelidir. Programlar, öğrencilerin algısal, yorumsal, çözümsel yetilerini geliştirici şekilde düzenlenmeli ve yaratıcı etkinlikleri kapsayan uygulamaları içermelidir. Ayrıca Eldemir'in de dediği gibi sanat eğitiminde meslek bilgisi derslerinin öğrenciyi sürekli aktif kılan yapıda tasarlanması önemlidir (Eldemir, 2011).

Program ders ve ders içerikleri değişirken bu dersleri verecek öğretmen adaylarının donanımları ve hangi atölyeden çıktıkları önemlidir. Bu nedenle Teknoloji Tasarım dersine girecek öğretmenlerin eğitimi de önemli olmalıdır. Öğretmen adaylarının öğrencilik dönemlerinde ETE’nin öneminin hem öğretmenlik 
ve hem de günlük işleyişimizdeki yerinin farkında olmaları sağlanmalıdır. Gökay Yılmaz (2009)'ın da belirttiği gibi davranışları gerektiği zaman ve yerde uygulayabilmek gereklidir. Öğrencilerin; dolayısıyla geleceği oluşturacak gençlerin, duygu ve düşüncelerini kendini rahat ve özgürce ifade edebilmek, algılama ve anlatım gücünü de geliştirebilmek adına sanat eğitimi son derece önemlidir. Eğitim sistemi sanatsal alanlarda bireyin yaratıcılığına ve yeteneklerine daha çok yer vermeli ve önemsemelidir. Öğretmen adaylarının araştırmacı-geliştirici-yaratıcı-çözümleyici bireyler olarak mezun olmaları gerekir. Sanatta özgürlük ve yaratıcılık önemlidir. Bu nedenle öğretmen, yaptırmak istediğini değil, çocuğun becerilerinin farkında olup onun yapmak istediğini yapmasına rehberlik eden, keşfeden, coşturan ve yol gösteren olmalıdır.

Sanatın toplumun gelişmesi açısından öneminin büyük olduğu herkes tarafından bilinmektedir. Mustafa Kemal Atatürk'ün de dediği gibi sanatsız kalan milletin hayat damarlarından biri kopmuş demektir. Sanata verilen önem sanatçı yetiştirmekten öte ilköğretimde bakmak değil görmeyi öğretmekten geçer, herkes bakar fakat herkes göremez. Dolayısıyla donanımlı öğretmenlerimizi yetiştirmek farklı bakış açıları ile onları mezun etmek son derece önemlidir. RïÖLP öğrencilerin toplum içerisindeki birey olma sürecinde önemli rolü olan entelektüel ve estetik donanımların sağlanmasında temel ve aynı zamanda sonuç olan başarının elde edilip sürdürülebilir hale gelmesinde önemli bir araç olan aktif uygulama çalışmalarını içinde barındıran Resim-iş Öğretmenliğinin hassasiyetinin en üst düzeyde bilinmesi ve göz ardı edilmemesi gerekir. Son olarak bu araştırmada elde edilen sonuçların, araştırma yaklaşımının doğası gereği bir genelleme amacı taşımadığı ve sadece Marmara Üniversitesi Resim-iş Öğretmenliği Anabilim Dalından mezun olan resim iş öğretmenlerinin görüşleri ve deneyimleri kapsamında değerlendirilmesi gerektiği dikkate alınmalıdır.

\section{Kaynakça}

Ayaydın, A. (2009). Görsel sanatlar eğitimi ve çoklu zeka kuramı. In A. Alakuş \& L. Mercin (Eds.), Sanat eğitimi ve görsel sanatlar öğretimi (pp. 183-196). Ankara: Pegem Akademi.

Ayaydın, A. (2011). Resim-iş öğretmeni yetiştirme programı ile görsel sanatlar dersi öğretim programı arasındaki uyum sorunları. Çukurova Üniversitesi Eğitim Fakültesi Dergisi, 40 (3), 26-33.

Buyurgan, S. (2007). Eğitim fakülteleri resim-iş eğitimi ana bilim dalı öğrencilerinin aldıkları eğitim ve öğretime ilişkin görüş ve beklentileri. Türk Eğitim Bilimleri Dergisi, 5 (4), 657-677.

Buyurgan, S. \& Buyurgan, U. (2012). Sanat eğitimi ve öğretimi. Ankara: Pegem Akademi.

Demirel, Ö. (1997). Kuramdan uygulamaya program geliştirme. Ankara: Kardeş Kitap ve Yayıncılık.

Eldemir, C. (2011). Müzik ve resim-iş eğitimi anabilim dalı öğrencilerinin öğretmenlik meslek bilgisi derslerine ilişkin görüşleri: Gazi üniversitesi örneği. Erciyes Üniversitesi Sosyal Bilimler Enstitüsü Dergisi, 30, 47-59.

Ertürk, S. (1993). Eğitimde program geliştirme. Ankara: Meteksan.

Gökay Yılmaz, M. (2009). Görsel sanatlar eğitimi. In A. Alakuş \& L. Mercin (Eds.), Sanat eğitimi ve görsel sanatlar öğretimi (pp. 13-18). Ankara: Pegem Akademi.

İz Bölükoğlu, H. (2002). Bilgi çağında eğitim fakültelerinde resim-iş eğitiminin genel bir değerlendirmesi. G.Ü. Gazi Eğitim Fakültesi Dergisi, 22 (3), 247-259.

Kavuran, T. (2003). Türkiye'de eğitim fakülteleri resim-iş öğretmenliği programlarının uygulamasında karşılaşılan sorunlar ve çözüm önerileri. Fırat Üniversitesi Sosyal Bilimler Dergisi, 13 (2), 167-190.

Kehnemuyi, Z. (2004). Çocuğun görsel sanat eğitimi. İstanbul: YKY.

Kırışoğlu, O. T. (2009). Sanat kültür yaratıcılık görsel sanatlar ve kültür eğitimi-öğretimi. Ankara: Pegem Akademi.

Kiprik, F. \& Şirin, N. (2012). Resim-iş öğretmenliği anabilim dallarında yapılan özel yetenek sınavlarına yönelik bir durum değerlendirmesi. İil, 1 (5), 328-338. 
MEB (1992). Illköğretim kurumları resim-iş dersi öğretim programı. Ankara: Milli Eğitim Basımevi.

MEB (2000). ilköğretim okulu resim-iş programı 6-7-8. sınıf. İstanbul: Milli Eğitim Basımevi.

MEB (2006a). Illköğretim sanat etkinlikleri dersi programı ve kılavuzu 1-5. sınıflar. Ankara: Pegem Yayınları.

MEB (2006b). Illköğretim teknoloji ve tasarım dersi öğretim programı ve kılavuzu (6, 7, 8. Sınıflar). Ankara: Millî Eğitim Bakanlığı Yayınları.

MEB (2010). Öğretmenlik için atama ve başvuru kılavuzu. Ankara: Milli Eğitim Bakanlığı.

Miles, M. B. \& Huberman, A. M. (1994). Qualitative data analysis: An expanded sourcebook. (2 ${ }^{\text {nd }}$ ed.). USA: SAGE Publications.

Oliva, P. F. (2001). Developing the curriculum. New York: Longman.

Özsoy, V. \& Şahan, M. (2009). Çok alanlı sanat eğitimi yönteminin ilköğretim 6. sınıf resim-iş dersinde öğrenci tutumuna etkisi. Türk Eğitim Bilimleri Dergisi, 7 (1), 205-227.

Peşkersoy, E. \& Yıldırım, O. (2010). Illköğretim görsel sanatlar dersi 1-8. sınıflar öğretmen kılavuz kitabı. Ankara: Milli Eğitim Bakanlığı.

Polat, A. A. (2013). Lisans eğitiminde alan derslerine dayalı başarı durumlarının değerlendirilmesi: S.Ü. güzel sanatlar fakültesi grafik bölümü örneği. idil, 2 (7), 226-254.

Sarı, S. (2000). Çağdaş sanat ve iş eğitimi açısından sınıf öğretmenliği lisans programı. Pamukkale Üniversitesi Eğitim Fakültesi Dergisi, 7, 1-6.

Türe, N. (2007). Eğitimde ve öğretimde bir araç olarak görsel sanatlar eğitiminin öğrencilere sağladığı katkılar. Unpublished master's thesis, Selçuk Üniversitesi Sosyal Bilimler Enstitüsü, Konya.

Uysal, A. (2005). İlköğretimde verilen sanat eğitimi derslerinin yaratıcılığa etkileri. Gazi Üniversitesi Kırşehir Eğitim Fakültesi Dergisi, 6 (1), 41-47.

Varış, F. (1988). Eğitimde program geliştirme. Ankara: Ankara Üniversitesi Yayınları.

Yıldırım, A. \& Şimşek, H. (2006). Sosyal bilimlerde nitel araştırma yöntemleri. Ankara: Seçkin Yayıncılık.

YÖK (1998). Eğitim fakültesi öğretmen yetiştirme lisans programları (Çoğaltma). Ankara.

Zeren, G. (2006). Bilgi çağı ve küreselleşme sürecinde sanat eğitimcisi kimliği sorunsalı. Kastamonu Eğitim Dergisi, 14 (2), 637-646. 
Şehnaz YALÇIN WELLS - Pegem Eğitim ve Öğretim Dergisi, 4(1) 2014, 75-102 